\title{
Deep ocean mass fluxes in the coastal upwelling off Mauritania from 1988 to 2012: variability on seasonal to decadal timescales
}

\author{
Gerhard Fischer $^{1,2}$, Oscar Romero ${ }^{2}$, Ute Merkel ${ }^{1,2}$, Barbara Donner $^{2}$, Morten Iversen $^{2,3}$, Nico Nowald $^{2}$, \\ Volker Ratmeyer $^{2}$, Götz Ruhland ${ }^{2}$, Marco Klann ${ }^{2}$, and Gerold Wefer ${ }^{2}$ \\ ${ }^{1}$ Geosciences Department, University of Bremen, Klagenfurter Strasse, 28359 Bremen, Germany \\ ${ }^{2}$ Marum Center for Marine and Environmental Sciences, Leobener Strasse, 28359 Bremen, Germany \\ ${ }^{3}$ Alfred Wegener Institute for Polar and Marine Research, Am Handelshafen, 27570 Bremerhaven, Germany \\ Correspondence to: Gerhard Fischer (gerhard.fischer@uni-bremen.de)
}

Received: 12 October 2015 - Published in Biogeosciences Discuss.: 3 November 2015

Revised: 10 May 2016 - Accepted: 12 May 2016 - Published: 27 May 2016

\begin{abstract}
A more than two-decadal sediment trap record from the Eastern Boundary Upwelling Ecosystem (EBUE) off Cape Blanc, Mauritania, is analysed with respect to deep ocean mass fluxes, flux components and their variability on seasonal to decadal timescales. The total mass flux revealed interannual fluctuations which were superimposed by fluctuations on decadal timescales. High winter fluxes of biogenic silica (BSi), used as a measure of marine production (mostly by diatoms) largely correspond to a positive North Atlantic Oscillation (NAO) index (December-March). However, this relationship is weak. The highest positive BSi anomaly was in winter 2004-2005 when the NAO was in a neutral state. More episodic BSi sedimentation events occurred in several summer seasons between 2001 and 2005, when the previous winter NAO was neutral or even negative. We suggest that distinct dust outbreaks and deposition in the surface ocean in winter and occasionally in summer/autumn enhanced particle sedimentation and carbon export on short timescales via the ballasting effect. Episodic perturbations of the marine carbon cycle by dust outbreaks (e.g. in 2005) might have weakened the relationships between fluxes and largescale climatic oscillations. As phytoplankton biomass is high throughout the year, any dry (in winter) or wet (in summer) deposition of fine-grained dust particles is assumed to enhance the efficiency of the biological pump by incorporating dust into dense and fast settling organic-rich aggregates. A good correspondence between BSi and dust fluxes was observed for the dusty year 2005, following a period of rather dry conditions in the Sahara/Sahel region. Large changes of all bulk fluxes occurred during the strongest El
\end{abstract}

Niño-Southern Oscillation (ENSO) in 1997-1999 where low fluxes were obtained for almost 1 year during the warm El Niño and high fluxes in the following cold La Niña phase. For decadal timescales, Bakun (1990) suggested an intensification of coastal upwelling due to increased winds ("Bakun upwelling intensification hypothesis"; Cropper et al., 2014) and global climate change. We did not observe an increase of any flux component off Cape Blanc during the past 2 and a half decades which might support this. Furthermore, fluxes of mineral dust did not show any positive or negative trends over time which might suggest enhanced desertification or "Saharan greening" during the last few decades.

\section{Introduction}

Eastern Boundary Upwelling Ecosystems (EBUEs; Fréon et al., 2009) cover only about $1 \%$ of the total ocean area but contribute with about $15 \%$ to total marine primary production (Carr, 2002; Behrenfeld and Falkowski, 1997). Roughly, $20 \%$ of the marine global fish catch is provided by the four major EBUEs (Pauly and Christensen, 1995), the Benguela, the Canary, the Californian and the Humboldt Current Systems. Continental margins may be responsible for more than $40 \%$ of the carbon sequestration in the ocean (Muller-Karger et al., 2005) and are thus highly relevant for the global carbon cycle. In the literature, multiple factors with potential influence on upwelling systems have been mentioned. To discuss all of them would be beyond the scope of this paper and we therefore focus on three major factors. 
In the 1990s, a discussion began whether global warming may lead to intensified coastal upwelling in the EBUEs (e.g. Bakun, 1990: "Bakun upwelling intensification hypothesis"; Cropper et al., 2014). Since then, various studies showed contradicting results, depending on the timescales regarded, the area studied and the methods applied. The longer-term time series analysis of wind stress and sea surface temperature (SST) by Narayan et al. (2010) from coastal upwelling areas seems to support the "Bakun upwelling intensification hypothesis", but correlation analysis showed ambiguous results concerning the relationships of upwelling to the North Atlantic Oscillation (NAO). With some modification, the "Bakun hypothesis" is supported for the Canary Current (CC) coastal upwelling system by Cropper et al. (2014). Using an upwelling index derived from SSTs and remote sensing wind stress, Marcello et al. (2011) obtained increased offshore spreading of upwelled waters off Cape Blanc from 1987 to 2006. Other authors, however, found a warming trend of the Canary Current System (e.g. Aristegui et al., 2009). Bode et al. (2009) observed a continuous decrease in upwelling intensity in the northern CC around the Canary Islands during the past 40 years, associated with the warming of surface waters, a decrease in zooplankton abundance, and, locally, in phytoplankton abundance. Studying a sediment core off Cape Ghir, Morocco, a cooling of the northern Canary Current in the 20th century was inferred (McGregor et al., 2007).

An influence of tropical Pacific interannual variability on EBUEs has also been proposed earlier. A link between the cold La Niña period (1997-1999 ENSO cycle) and the Mauritanian upwelling via a strengthening of the northeasterly (NE) trade winds in autumn and winter was described by Pradhan et al. (2006). Helmke et al. (2005) correlated these anomalous events with deep-ocean carbon fluxes at the mesotrophic Cape Blanc study site. Using ocean colour data, Fischer et al. (2009b) showed a large extension of the Cape Blanc filament from autumn 1998 to spring 1999 when comparing it to the rest of the record (1997-2008). Using remote-sensing data, Nykjaer and Van Camp (1994) found a weak northwest upwelling south of $20^{\circ} \mathrm{N}$ during and after the strong 1982-1983 El Niño event.

The NW African margin and the low-latitude North Atlantic are heavily influenced by Saharan dust transport, deposition (e.g. Kaufman et al., 2005) and sedimentation (Brust et al., 2001). Dust particles influence the earth's radiation balance and supply micro-nutrients (e.g. iron) and macronutrients to the ocean surface waters (e.g. Jickells et al., 2005; Neuer et al., 2004). Additionally, dust acts as ballast mineral (Armstrong et al., 2002; Klaas and Archer, 2002) for organic carbon-rich particles (e.g. Fischer et al., 2009a, b; Bory and Newton, 2000; Iversen and Ploug, 2010; Iversen et al., 2010; Bressac et al., 2014). Dunne et al. (2007) suggested that dust may be the major carrier for organic carbon to the seafloor. A clear coupling between atmospheric dust occurrence and deep-sea lithogenic particle fluxes at $2000 \mathrm{~m}$ water depths was observed in the subtropical north Atlantic $\left(33^{\circ} \mathrm{N}\right.$, $22^{\circ} \mathrm{W}$; Brust et al., 2011). Fischer and Karakas (2009) proposed that high dust supply may increase particle settling rates by ballasting and result in relatively high organic carbon fluxes in the Canary Current system compared to other EBUEs. Wintertime African dust transport is suggested to be affected by the NAO (Chiapello et al., 2005; Hsu et al., 2012). As dust plays a major role in the Cape Blanc area with respect to deep ocean fluxes and the intensity of coastal upwelling is affected by the NAO as well, the major focus of this long-term study will be on the relationship between deep ocean mass fluxes and NAO forcing.

From the mesotrophic Cape Blanc study site $\mathrm{CB}_{\text {meso }}$ located about 200 nautical miles off the coast (Fig. 1a), we obtained an almost continuous sediment trap record of fluxes (mostly from about $3500 \mathrm{~m}$ water depth) for the past 25 years (1988-2012, only interrupted between 1992 and 1993). Long time series of particle fluxes are rare, in particular from coastal upwelling sites with high productivity. Although SSTs and wind data analyses over longer timescales (e.g. decades) for the NW African upwelling system and other EBUEs are very important to test the "Bakun upwelling intensification hypothesis" (Bakun, 1990; Cropper et al., 2014), any potential increase of upwelling intensity does not necessarily result in an increase of phytoplankton standing stock and/or productivity and/or deep ocean mass fluxes (e.g. Ducklow et al., 2009). Hence, for studying the potential changes of the biological pump and carbon sequestration in the deep ocean over decades and over a larger area, sediment traps are a primary and probably the best choice. As deep ocean sediment traps have a rather large catchment area for particles formed in the surface and subsurface waters (e.g. Siegel and Deuser, 1997), they integrate rather local and small-scale effects, events and processes in the highly dynamic EBUE off Mauritania.

\section{Study area}

\subsection{Oceanographic and biological setting}

The sediment trap mooring array $\mathrm{CB}_{\text {meso }}$ is deployed in the Canary Current System within one of the four major EBUEs (Fréon et al., 2009) (Fig. 1a). Coastal upwelling is driven there by alongshore trade winds, leading to offshore advection of surface waters, which are replaced by colder and nutrient-rich subsurface waters. Around $21^{\circ} \mathrm{N}$ off Cape Blanc, a prominent cold filament leads to offshore streaming of cold and nutrient-rich waters from the coast to the open ocean up to about $450 \mathrm{~km}$ offshore (Fig. 1a). This cold tongue is named the "giant Cape Blanc filament" (Van Camp et al., 1991), being one of the largest filaments within all EBUEs.

The relationship between the coastal winds, SST and the biological response (e.g. changes in chlorophyll) off Mauritania seems to be strong and almost immediate (Mittelstaedt, 


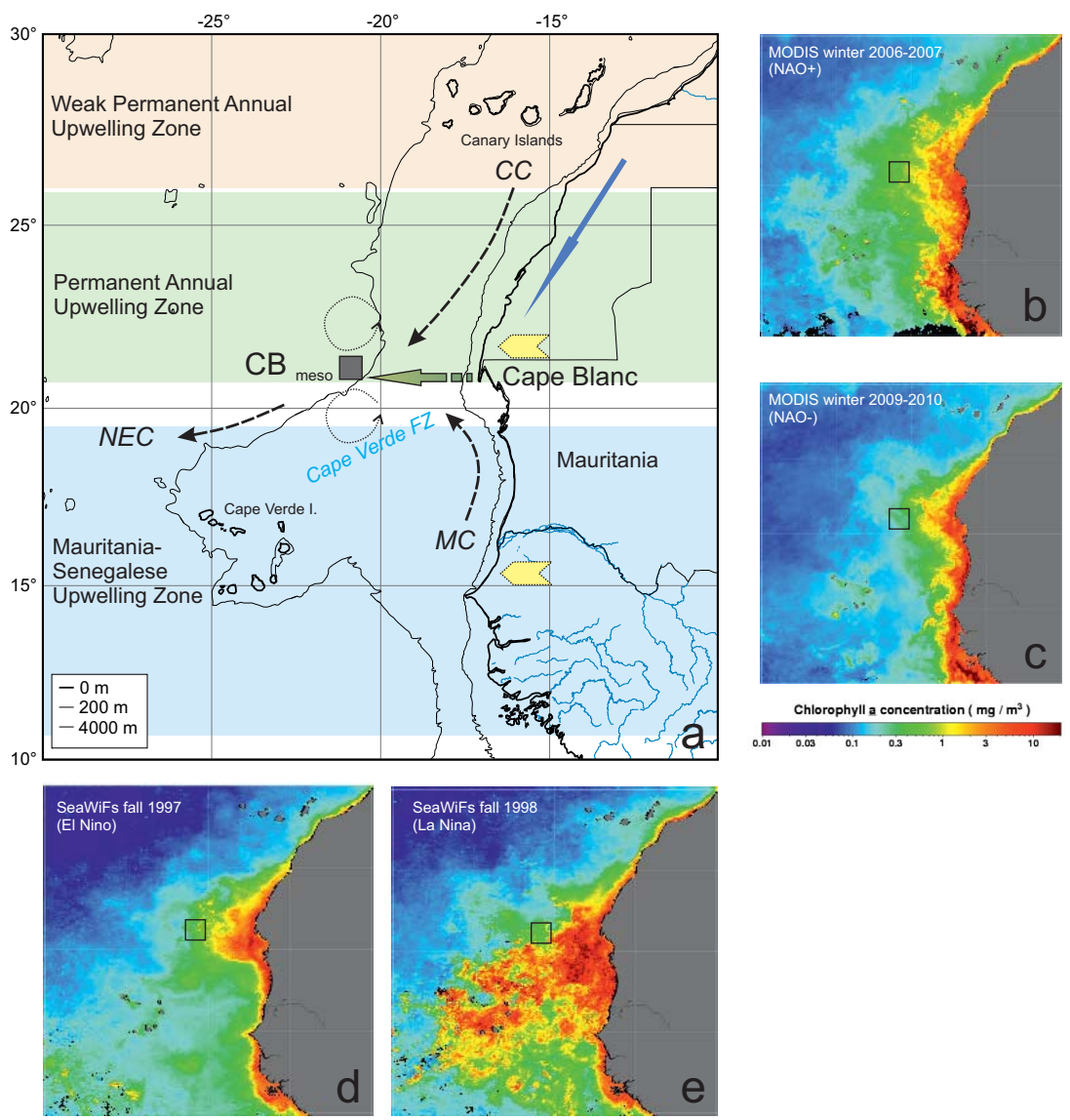

Figure 1. General setting of the study area: (a) Oceanographic setting in the area of the long-term mooring site Cape $\mathrm{Blanc}\left(\mathrm{CB}_{\text {meso }}\right)$ within the Cape Blanc filament (green arrow), dissolving into eddies (indicated as circles with arrows) further offshore. The Cape Verde Frontal Zone (CVFZ) separating the subsurface water masses of the NACW and the SACW (Zenk et al., 1991) is shown. Upwelling zones are marked according to Cropper et al. (2014). Ocean colour map (chlorophyll, $9 \mathrm{~km}$ resolution) from MODIS is shown for 2 extreme years, winter 2006-2007 (b, NAO+) and winter 2009-2010 (c, NAO-). SeaWiFS ocean colour during two contrasting situations for the strongest ENSO cycle 1997-1999: autumn 1997 during the warm El Niño phase (d), and autumn 1998 during the cold La Niña event (e). The study site $\mathrm{CB}_{\text {meso }}$ is indicated by a square box in the ocean colour pictures, green arrow indicates the Cape Blanc filament, yellow arrows the major dust transport. $\mathrm{MC}=$ Mauritanian Current, $\mathrm{CC}=$ Canary Current, $\mathrm{NEC}=$ North Equatorial Current.

1991; Pradhan et al., 2006). Trade winds persist throughout the year and intensify in late winter to reach their highest intensity in spring (Barton et al., 1998; Nykjaer and Van Camp, 1994; Meunier et al., 2012). According to Lathuilière et al. (2008), our study area is located within the Cape Blanc inter-gyre region $\left(19-24^{\circ} \mathrm{N}\right)$ which is characterized by a weaker seasonality (peaks in winter-spring and autumn). Following the definition by Cropper et al. (2014), our study area is situated on the southern rim of the strong and permanent coastal upwelling zone $\left(21-26^{\circ} \mathrm{N}\right)$ (Fig. 1a).

The cold and nutrient-rich southward flowing CC departs from the coastline south of Cape Blanc, later forming the North Equatorial Current (NEC) (Fig. 1a). South of about $20^{\circ} \mathrm{N}$, a recirculation gyre drives a poleward coastal current fed by the North Equatorial Counter Current (NECC) during summer. The Mauritanian Current (MC) flows northward along the coast to about $20^{\circ} \mathrm{N}$ (Fig. 1a; Mittelstaedt, 1991), bringing warmer surface water masses from the equatorial realm into the study area. Where the CC departs from the coast, a NE-SW orientated salinity front in the subsurface waters is observed, the Cape Verde Frontal Zone (CVFZ, Zenk et al., 1991) (Fig. 1a), which separates the salty and nutrient-poor North Atlantic Central Water (NACW) from the nutrient-richer and cooler South Atlantic Central Water (SACW). Both water masses may be upwelled and mixed laterally and frontal eddies develop off Cape Blanc (Meunier et al., 2012) (Fig. 1a). Lathuilière et al. (2008) offered a comprehensive overview of the physical background, i.e. the ocean circulation off NW Africa. 


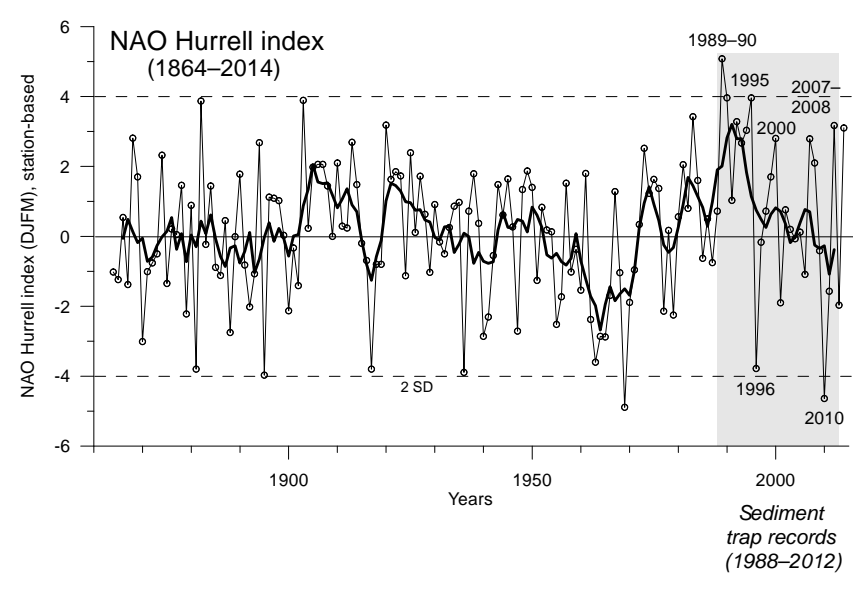

Figure 2. The NAO Hurrell index (DJFM, station-based, LisbonRejkjavik, Hurrell, 1995) plotted from 1864-2014. Grey shading indicates the time period covered by the long-term flux record off Cape Blanc, Mauritania. A 5-point running mean is shown by the thick line.

\subsection{Importance of dust supply and Sahel rain fall for the study area}

Dust supply from land to the low-latitude North Atlantic Ocean is not only dependent on the strength of the transporting wind systems (NE trade winds at lower levels and Saharan Air Layer above) but also on the rainfall and dryness in the multiple source regions in West Africa (Goudie and Middleton, 2001; Nicholson, 2013). During long periods of droughts (e.g. in the 1980s), dust loadings over the Sahel experienced extraordinary increases (N'Tchayi Mbourou et al., 1997). As mass fluxes and settling rates of larger marine particles (i.e. marine snow) are assumed to be influenced by mineral dust particles via the ballasting effect (Armstrong et al., 2002; Fischer et al., 2009a, 2010; Iversen and Ploug, 2010; Bressac et al., 2014; Dunne et al., 2007; Thunell et al., 2007), climatic conditions on land need to be considered. The contribution of dust to the settling particles in the deep ocean off Cape Blanc amounts to one-third on average of the total mass flux (Fischer et al., 2010), but it may be as high as $50 \%$ during particular flux events (Nowald et al., 2015). As shown by Jickells et al. (2005), modelled dust fluxes from the Saharan region and their variability may be influenced by ENSO and NAO cycles (see also Goudie and Middleton, 2001; Chiapello et al., 2005; Hsu et al., 2012; Diatta and Fink, 2014). During the time period of this study (1988-2012, Fig. 2), the wintertime (December-JanuaryFebruary-March = DJFM) NAO index after Hurrell (Hurrell, 1995) is characterized by switches from extremely positive (e.g. 1989, 1990) to extremely negative values (e.g. in 1996, 2010).

Climate over West Africa is also influenced by the continental Inter-Tropical Convergence Zone (ITCZ; also named Intertropical Front, Nicholson, 2013). This low-pressure zone separates the warm and moist SW monsoon flow from the dry NE trade winds coming from the Sahara. The tropical rainbelt in the Atlantic realm originates from the convergence of the NE and SE trade wind systems and migrates roughly between $\sim 3^{\circ} \mathrm{S}$ (boreal winter) and $\sim 15^{\circ} \mathrm{N}$ (boreal summer) in the course of the year (Lucio et al., 2012). On longer timescales, severe Sahel drought intervals occurred in the 1980s (Chiapello et al., 2005; Nicholson, 2013). Recent evidence shows that Sahel rainfall may have recovered during the last 2 decades and that the region is now "greening" (Fontaine et al., 2011; Lucio et al., 2012).

\subsection{Large-scale teleconnections affecting the study area}

Ocean-atmosphere dynamics at our study site is influenced by large-scale atmospheric teleconnections and climate modes. Here, such teleconnections are illustrated based on results from a long-term present-day climate control run which was performed using the Comprehensive Climate System Model version 3 (CCSM3; Collins et al., 2006; Yeager et al., 2006). Atmospheric sea-level pressure (SLP) patterns describe the near-surface air flow which affects ocean upwelling and currents as well. We therefore correlated simulated SLP with prominent teleconnection indices such as the NAO SLP index (Hurrell, 1995) and the Niño3 area-averaged $\left(150-90^{\circ} \mathrm{W}, 5^{\circ} \mathrm{S}-5^{\circ} \mathrm{N}\right) \mathrm{SST}$ index, both calculated from the model results (Fig. 3). Boreal winter is the season where the NAO is strongest and where tropical Pacific SST anomalies associated with ENSO events tend to peak.

Correlations during winter show that NAO and ENSO may have opposite effects on the NW African/eastern Atlantic realm (Fig. 3a, b), for instance on wind fields, and consequently on upwelling with potential implications for deep ocean mass fluxes. A positive phase of the NAO is associated with anomalous high pressure in the Azores high region (Fig. 3a) and stronger northeasterly winds along the NW African coast. In contrast, a positive phase of ENSO (El Niño event) goes along with a weakening of the northeasterlies in the study area (Fig. 3b). It should be noted, however, that the magnitude of correlation in our study area is larger for the NAO than for ENSO. This should be taken into account when disentangling the relative importance of these climate modes. Apart from seasonal-to-interannual timescales, lowfrequent climate variability may impact on our study area as well and is probably linked to Atlantic SST variations on decadal-to-interdecadal timescales, e.g. the Atlantic Multidecadal Oscillation (AMO). The correlation of SLP with area-averaged $\left(0-70^{\circ} \mathrm{N}, 60-10^{\circ} \mathrm{W}\right)$ SST fluctuations over periods above 10 years highlights a centre of action in the tropical Atlantic with SLP reductions (weaker northeasterly winds) along with higher Atlantic basin-wide SST during a positive AMO phase (Fig. 3c). This shows the potential importance of longer-term Atlantic basin-scale SST variations for alongshore winds and upwelling (trends) at our trap location. 

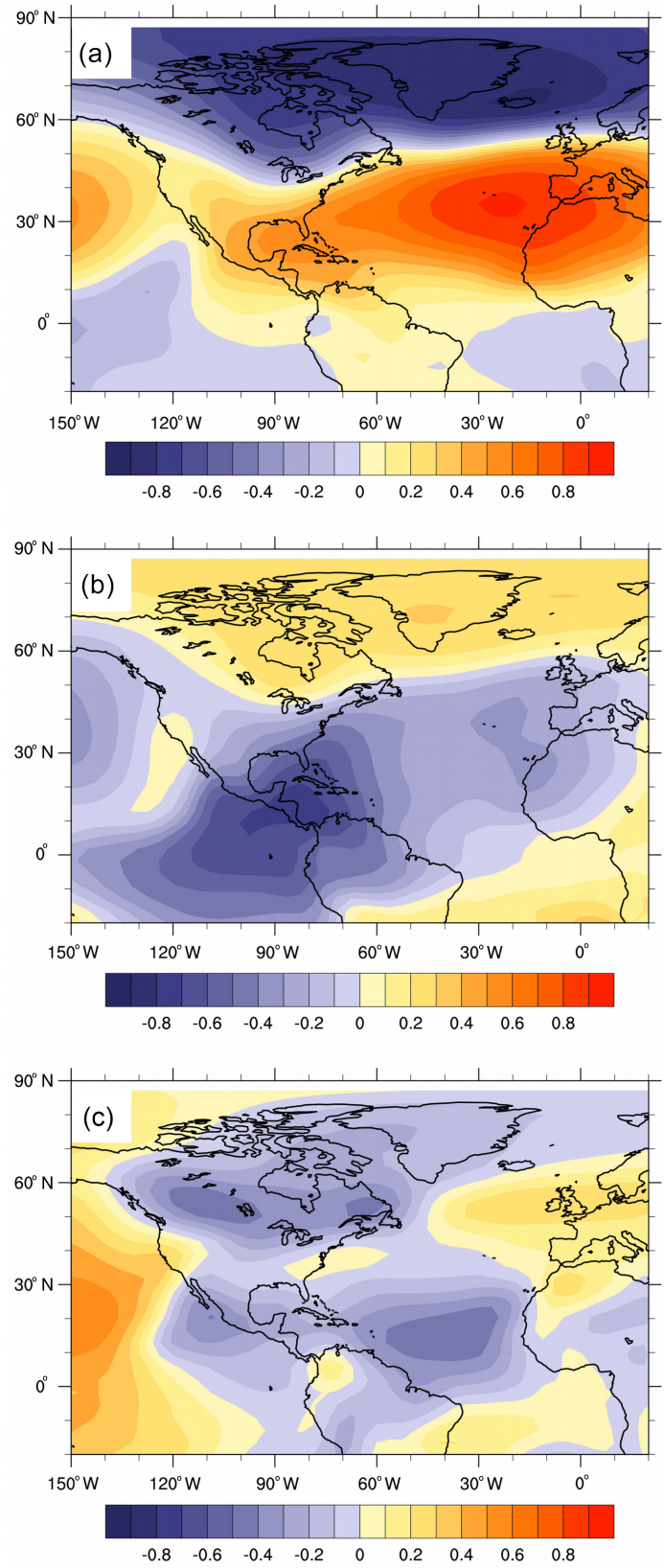

Figure 3. Teleconnections affecting the study site off Cape Blanc. Correlation of simulated sea-level pressure (SLP) with (a) the NAO SLP index after Hurrell (Hurrell, 1995; boreal winter season), (b) the Nino3 SST index (boreal winter season), and (c) North Atlantic SST (low pass-filter applied considering periods above 10 years). Analysis based on the last 100 model years of a presentday control simulation using the CCSM3 model.

ENSO-related teleconnections in the NW African upwelling system have been described by several authors (Behrenfeld et al., 2001; Pradhan et al, 2006; Zeeberg et al., 2008) and can be illustrated by the negative correlation of SLP with eastern tropical Pacific SST (Fig. 3b). Fischer et al. (2009b) showed that the size of the Cape Blanc fila- ment was small in winter-spring 1997-1998 and unusually high from autumn 1998 to spring 1999 (Figs. 7b, 1e). This is documented by reduced (warm El Niño) and elevated (cold La Niña) deep ocean mass fluxes of all components. In certain years, the filament area was more than twice as large in spring as in fall (e.g. 1999 La Niña Event). Tropical Pacific variability on interannual ENSO timescales is also an important factor in driving ecosystem variability in the California Current System (for a summary see Checkley and Barth, 2009).

\section{Material and methods}

\subsection{Sediment traps and moorings}

We used deep-moored (>1000 m), large-aperture time series sediment traps of the Kiel and Honjo type with 20 cups and $0.5 \mathrm{~m}^{2}$ openings, equipped with a honeycomb baffle (Kremling et al., 1996). Mooring and sampling dates are given in Table 1 . As the traps were moored in deep waters (mostly below $1000 \mathrm{~m}$ ), uncertainties with the trapping efficiency due to strong currents (e.g. undersampling, Yu et al., 2001; Buesseler et al., 2007) and/or due to the migration and activity of zooplankon migrators ("swimmer problem") are assumed to be minimal. Prior to the deployments, the sampling cups were poisoned with $\mathrm{HgCl}_{2}$ ( $1 \mathrm{~mL}$ of conc. $\mathrm{HgCL}_{2}$ per $100 \mathrm{~mL}$ of filtered seawater) and pure $\mathrm{NaCl}$ was used to increase the salinity and density in the sampling cups (salinity $=40 \%$ o). Upon recovery, samples were stored at $4{ }^{\circ} \mathrm{C}$ and wet-splitted in the home laboratory using a rotating McLane wet splitter system. Larger swimmers such as crustaceans were picked by hand with forceps and were removed by filtering carefully through a $1 \mathrm{~mm}$ sieve and all flux data therefore refer to the size fraction of $<1 \mathrm{~mm}$. In almost all samples, the fraction of particles $>1 \mathrm{~mm}$ was negligible, only in a few samples, larger pteropods were found.

\subsection{Mass fluxes}

Analysis of the fraction $<1 \mathrm{~mm}$, using $1 / 4$ or $1 / 5$ wet splits, was performed according to Fischer and Wefer (1991). Samples were freeze-dried and the homogenized samples were analysed for bulk (total mass), organic carbon, total nitrogen, carbonate and biogenic opal ( $\mathrm{BSi}=$ biogenic silica). Organic carbon, nitrogen and calcium carbonate were measured by combustion with a CHN-Analyser (HERAEUS). Organic carbon was measured after removal of carbonate with $2 \mathrm{~N}$ $\mathrm{HCl}$. Overall analytical precision based on internal lab standards was better than $0.1 \%( \pm 1 \sigma)$. Carbonate was determined by subtracting organic carbon from total carbon, the latter being measured by combustion without pre-treatment with $2 \mathrm{~N} \mathrm{HCl}$. BSi was determined with a sequential leaching technique with $1 \mathrm{M} \mathrm{NaOH}$ at $85^{\circ} \mathrm{C}$ (Müller and Schneider, 1993). The precision of the overall method based on replicate analyses is mostly between \pm 0.2 and $\pm 0.4 \%$, depending on 
Table 1. Deployment data of the moorings and traps at the mesotrophic sediment trap site CB, Cape Blanc, Mauritania. Associated ships' cruises and references to earlier publications on fluxes are indicated.

\begin{tabular}{|c|c|c|c|c|c|c|c|c|c|}
\hline $\begin{array}{l}\text { Trap } \\
\text { name }\end{array}$ & $\begin{array}{l}\text { LAT } \\
\mathrm{N}\end{array}$ & $\begin{array}{l}\text { LONG } \\
\mathrm{W}\end{array}$ & $\begin{array}{r}\text { water depth } \\
\mathrm{m}\end{array}$ & $\begin{array}{r}\text { trap depth } \\
\mathrm{m}\end{array}$ & $\begin{array}{r}\text { sampling } \\
\text { start }\end{array}$ & end & $\begin{array}{r}\text { no } \\
\text { of samples }\end{array}$ & $\begin{array}{l}\text { remark, } \\
\text { reference to fluxes }\end{array}$ & $\begin{array}{l}\text { relevant cruise recovery/ } \\
\text { GeoB no. }\end{array}$ \\
\hline CB-1 lower & $20^{\circ} 45.3^{\prime}$ & $19^{\circ} 44.5^{\prime}$ & 3646 & 2195 & 22.03 .88 & 08.03 .89 & 13 & Fischer et al. $(1996,2003)$ & Meteor 9/4/ GeoB 1121-4 \\
\hline CB-2 lower & $21^{\circ} 08.7^{\prime}$ & $20^{\circ} 41.2^{\prime}$ & 4092 & 3502 & 15.03 .89 & 24.03 .90 & 22 & Fischer et al. $(1996,2003)$ & Meteor $12 / 1 /$ GeoB 1230-1 \\
\hline CB-3 lower & $21^{\circ} 08.3^{\prime}$ & $20^{\circ} 40.3^{\prime}$ & 4094 & 3557 & 29.04 .90 & 08.04 .91 & 17 & Fischer et al. $(1996,2003,2010)$ & Polarstern ANT IX/4 \\
\hline CB-4 lower & $21^{\circ} 08.7^{\prime}$ & $20^{\circ} 41.2^{\prime}$ & 4108 & 3562 & 03.03 .91 & 19.11 .91 & 13 & Fischer et al. $(1996,2003,2010)$ & Meteor 20/1/ GeoB 1602-1 \\
\hline CB-5 lower & $21^{\circ} 08.6^{\prime}$ & $20^{\circ} 40.9^{\prime}$ & 4119 & 3587 & 06.06 .94 & 27.08 .94 & 19 & & Meteor 29/3/ GeoB 2912-1 \\
\hline CB-6 upper & $21^{\circ} 15.0^{\prime}$ & $20^{\circ} 41.8^{\prime}$ & 4137 & 771 & 02.09 .94 & 25.10 .95 & 20 & Fischer et al. (2010) & Polarstern ANT XIII/1 \\
\hline CB-7 lower & $21^{\circ} 15.4^{\prime}$ & $20^{\circ} 41.8^{\prime}$ & 4152 & 3586 & 20.11 .95 & 29.01 .97 & 20 & & Meteor 38/1/ GeoB 4302-7 \\
\hline CB-8 upper & $21^{\circ} 16.3^{\prime}$ & $20^{\circ} 41.5^{\prime}$ & 4120 & 745 & 30.01 .97 & 04.06 .98 & 20 & Fischer et al. (2010) & Meteor 41/4/ GeoB 5210-2 \\
\hline CB-9 lower & $21^{\circ} 15.2^{\prime}$ & $20^{\circ} 42.4^{\prime}$ & 4121 & 3580 & 11.06 .98 & 07.11 .99 & 20 & Helmke et al. (2005) & Metero 46/1/ GeoB 6103-3 \\
\hline CB-10 lower & $21^{\circ} 17.2^{\prime}$ & $20^{\circ} 44.1^{\prime}$ & 4125 & 3586 & 10.11 .99 & 10.10 .00 & 3 & mostly no seasonal sampling & Polarstern ANT XVIII/1 \\
\hline CB-11 upper & $21^{\circ} 16.8^{\prime}$ & $20^{\circ} 43.0^{\prime}$ & 4113 & 1003 & 11.10 .00 & 30.03 .01 & 20 & & Poseidon 272/ GeoB 7401-1 \\
\hline CB-12 lower & $21^{\circ} 16.0^{\prime}$ & $20^{\circ} 46.5$ & 4145 & 3610 & 05.04 .01 & 22.04 .02 & 14 & & Meteor 53/1c/ GeoB 7917-1 \\
\hline CB-13 lower & $21^{\circ} 16.8^{\prime}$ & $20^{\circ} 46.7^{\prime}$ & 4131 & 3606 & 23.04 .02 & 08.05 .03 & 20 & $\begin{array}{l}\text { Fischer et al. (2009b) } \\
\text { Fischer and Karakas (2009) }\end{array}$ & Meteor 58/2b/ GeoB 8628-1 \\
\hline CB-14 upper & $21^{\circ} 17.2^{\prime}$ & $20^{\circ} 47.6^{\prime}$ & 4162 & 1246 & 31.05 .03 & 05.04 .04 & 20 & & Poseidon $310 /$ no number \\
\hline CB-15 lower & $21^{\circ} 17.9^{\prime}$ & $20^{\circ} 47.8^{\prime}$ & 4162 & 3624 & 17.04 .04 & 21.07 .05 & 20 & & Meteor $65 / 2 /$ no number \\
\hline CB-16 lower & $21^{\circ} 16.8^{\prime}$ & $20^{\circ} 47.8^{\prime}$ & 4160 & 3633 & 25.07 .05 & 28.09 .06 & 20 & & Poseidon 344/1/ GeoB 11401-1 \\
\hline CB-17 lower & $21^{\circ} 16.4^{\prime}$ & $20.48 .2^{\prime}$ & 4152 & 3614 & 24.10 .06 & 25.03 .07 & 20 & & Merian $04 / \mathrm{b} /$ GeoB $11833-1$ \\
\hline CB-18 lower & $21^{\circ} 16.9^{\prime}$ & $20^{\circ} 48.1^{\prime}$ & 4168 & 3629 & 25.03 .07 & 05.04 .08 & 20 & & Poseidon 365/2/ GeoB 12907-1 \\
\hline CB-19 lower & $21^{\circ} 16.2^{\prime}$ & $20^{\circ} 48.7^{\prime}$ & 4155 & 3617 & 22.04 .08 & 22.03 .09 & 20 & & Merian 11/2/ GeoB 13616-4 \\
\hline CB-20 upper & $21^{\circ} 15.6^{\prime}$ & $20^{\circ} 50.7^{\prime}$ & 4170 & 1224 & 03.04 .09 & 26.02 .10 & 19 & & Poseidon 396/ GeoB 14201-3 \\
\hline CB-21 lower & $21^{\circ} 15.6^{\prime}$ & $20^{\circ} 50.9^{\prime}$ & 4155 & 3617 & 28.02 .10 & 04.04 .11 & 20 & & Merian 18/1/ GeoB 15709-1 \\
\hline CB-22 lower & $21^{\circ} 16.1^{\prime}$ & $20^{\circ} 50.9^{\prime}$ & 4160 & 3622 & 05.05 .11 & 11.01 .12 & 15 & & Poseidon 425/ GeoB 16101-1 \\
\hline CB-23 lower & $21^{\circ} 15.8^{\prime}$ & $20^{\circ} 52.4^{\prime}$ & 4160 & 3622 & 20.01 .12 & 22.01 .13 & 18 & & Poseidon 445/ GeoB 17102-5 \\
\hline
\end{tabular}

the material analysed. For a detailed table of standard deviations for various samples we refer to Müller and Schneider (1993). Lithogenic fluxes or the non-biogenic material was estimated according to

lithogenic material $=$ dust $=$ total mass - carbonate

$$
- \text { opal }-2 \times \mathrm{C}_{\text {org }} \text {. }
$$

We estimated organic matter by multiplying organic carbon by a factor of two as about $50-60 \%$ of marine organic matter is constituted by organic carbon (Hedges et al., 1992). Some studies have shown a clear linear relationship between lithogenic fluxes and particulate aluminum (e.g. Ratmeyer et al., 1999a), the latter being derived from clay minerals as part of the lithogenic (non-biogenic) component. Grains size studies from Ratmeyer et al. (1999a, b) and further microscopic analysis provide evidence that most of the lithogenic material in the study area was derived from quartz grains in the fine silt fraction (10-30 $\mu \mathrm{m}$, see also Friese et al., 2016). Here we attribute the lithogenic flux to dust-derived material (= mineral dust flux $)$ as no large rivers supply suspended material to the study area off Cape Blanc.

Due to logistical reasons, we had very different time resolutions of the sediment trap collections (a few days to several weeks) which limits comparisons between specific intervals and years. Seasonal fluxes were calculated and shown to allow comparison between the seasons mainly with respect to interannual variability. Seasons were defined using the dates of opening and closure of the sampling cups closest to the start of the astronomical seasons (21 March, 21 June, 23 September, 21 December) (Table 2). Where lower trap data (around $3500 \mathrm{~m}$ ) were not available, the upper trap data (around $1000 \mathrm{~m}$ ) were used, which mostly match the lower trap fluxes with respect to seasonality (Fischer et al., 2009b). When plotting all available lower and upper trap total mass fluxes for winter, a close correspondence is observed $\left(r^{2}=0.84, N=10\right)$, with slightly higher fluxes in the deeper trap due to lateral particle advection processes (Fischer et al., 2009b; Karakas et al., 2006, 2009). However, considering the entire record presented here, it seems that the upper trap fluxes of the winter seasons 1998 and 2004 may be critical due to smaller filament areas. As a consequence, the area/filament with elevated chlorophyll and high particle concentrations may not have reached the upper offshore trap. Because of lateral particle advection from the east (Karakas et al., 2006) and the larger catchment area of the deeper traps (Siegel and Deuser, 1997), particle fluxes might have been higher in the deeper water column in winter 1998 and 2004. In general, the seasonal patterns and the composition of the particle fluxes were rather similar between the upper and lower traps (Fischer et al., 2009b). The long-term means and standard deviations were calculated using only the available deeper trap flux values. The seasonal anomalies of the bulk fluxes were calculated using the deviations from the mean values of the respective seasons.

\subsection{Carbonate producers}

To determine the major carbonate producers, the trap material was carefully wet-sieved with a $1 \mathrm{~mm}$ screen and split into aliquots by a rotary liquid splitter. Generally a $1 / 5$ split of the $<1 \mathrm{~mm}$ fraction was used to pick planktonic foraminifers and pteropods from the wet solution. Foraminifers and pteropods were picked by hand 


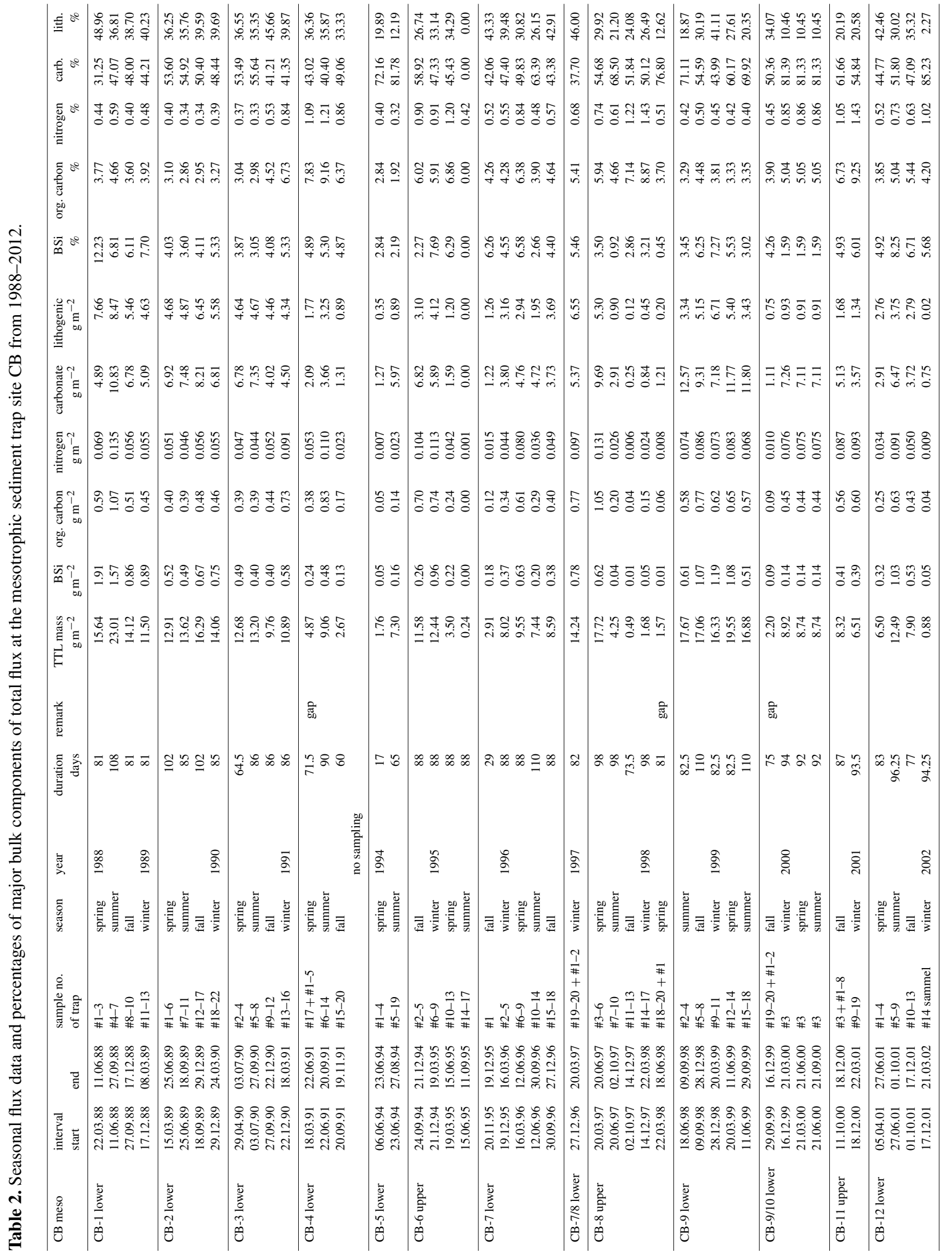




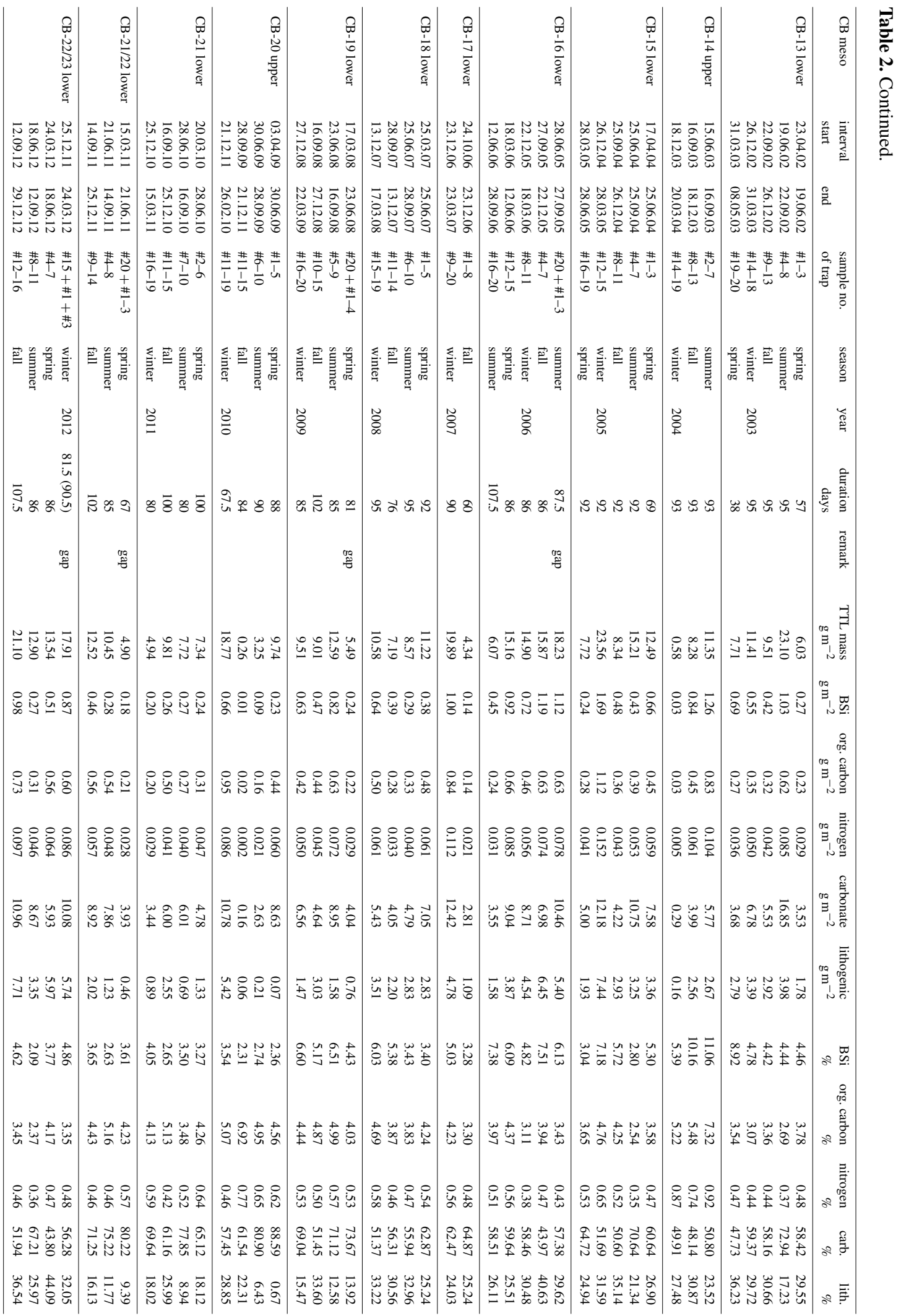


with a pipette under a ZEISS Stemi 2000 microscope and rinsed with fresh water for three times and dried at $50{ }^{\circ} \mathrm{C}$ overnight and counted. The mass fluxes of total carbonate producers expressed as $\mathrm{mg} \mathrm{m}^{-2} \mathrm{~d}^{-1}$ are mainly constituted of planktonic foraminifera, pteropods and nannofossils/coccolithophorids. Masses of foraminifera and pteropods were determined with a Sartorius BP 211D analytical balance.

\subsection{Additional web-based data}

To put our flux results from the deep ocean into a broader context, we used several observational data sets available from several of the websites given below. For ocean colour, time series from the MODIS or SeaWiFS sensors based on a $1^{\circ} \times 1^{\circ}$ box from $20-21^{\circ} \mathrm{N}$ and $21-20^{\circ} \mathrm{W}(9 \mathrm{~km}$ resolution) slightly to the east of the study site CB have been chosen due to the generally prevailing E-W directed current system, transporting particles to the west (Helmke et al., 2005). Larger boxes, e.g. $2^{\circ} \times 2^{\circ}$ or $4^{\circ} \times 4^{\circ}$, revealed similar results. For the aerosol optical thickness (AOT, $869 \mathrm{~nm}, 9 \mathrm{~km}$ resolution), a $1^{\circ} \times 1^{\circ}$ box was chosen from the SeaWiFS and MODIS data.

\section{Results}

In the long term, seasonal bulk fluxes were highest in boreal winter and summer and slightly lower in spring and autumn (Figs. 4, 5, 6a; Table 2). Total bulk fluxes reached 23.6 and $23.1 \mathrm{~g} \mathrm{~m}^{-2}$ in winter and summer, respectively (Table 2). For spring and autumn, total mass fluxes were as high as 19.6 and $21.1 \mathrm{~g} \mathrm{~m}^{-2}$, respectively (Table 2). However, the seasonal differences in the bulk fluxes are not statistically significant. Along with the highest mass fluxes, winter and summer seasons also exhibit the highest standard deviations (Fig. 4), pointing to a high interannual variability. In general, this interannual variability is clearly higher than the seasonal differences in bulk fluxes. Only the lithogenic components, i.e. the mineral dust particles, did not show an increase during summer and only peaked in winter (up to $7.4 \mathrm{~g} \mathrm{~m}^{-2}$ ) when dust plumes were most frequent (Goudie and Middleton, 2001). High summer fluxes of up to $16.9 \mathrm{~g} \mathrm{~m}^{-2}$ were mostly due to high carbonate sedimentation (Fig. 4), both of primary (coccolithophores) and secondary producers (foraminifera and pteropods). Organic carbon and BSi showed a rather similar pattern (Figs. 4, 6a) with a maximum in winter (up to 1.1 and $1.7 \mathrm{~g} \mathrm{~m}^{-2}$, respectively) and a secondary maximum in summer/autumn. This is reflected in the close correspondence between both flux components for these seasons (Table 3). Highest mass fluxes coinciding with highest positive flux anomalies lasting for several seasons occurred in 19881989, 1998-1999, and 2005-2006 (Fig. 5).
Following the strong ENSO cycle 1997-1999, total flux anomalies were low or negative over a longer period (autumn 1999 to autumn 2004), only interrupted by an episodic peak in summer 2002 (Fig. 5a, b). Other episodic peaks in sedimentation were found in winter/spring 1996-1997 and in the winter seasons 2004-2005, 2006-2007 and 2009-2010 (Fig. 5a, b). Longer intervals (several seasons) of negative flux anomalies were obtained in 1997-1998 and 2009-2011 (Fig. 5b). Total fluxes decreased from 1988 to 1991, from spring 2007 to 2010, later increasing from 2010 to 2012 (Fig. 5).

In general, the major bulk flux components followed the total flux and were well inter-correlated, except that the relationship between organic carbon and carbonate was weak in summer (Table 3). However, the regression-based relationships (i.e. the slope) varied interannually (e.g. Fischer et al., 2009a). The matrix in Table 3 shows the correlation coefficients between organic carbon and nitrogen, BSi, carbonate and lithogenic fluxes for the four seasons (lower traps only). Organic carbon and BSi (mainly diatoms) were highly correlated during the major upwelling events in winter $\left(R^{2}=0.70\right)$ and summer/autumn, whereas the relationship between organic carbon and total carbonate in summer was weak $\left(R^{2}=0.16\right.$, Table 3$)$. Dust fluxes peaked together with organic carbon, preferentially in winter and autumn $\left(R^{2}=0.63\right.$ and 0.67 , respectively Table 3$)$. The tight coupling between organic carbon and nitrogen is not surprising as both elements constitute organic matter formed during photosynthesis, which is later degraded in the upper water column forming sinking phytodetritus. The slope is almost constant (0.13-0.11) and the reciprocal value reflects the Redfield Ratio (Redfield et al., 1963) of the sinking organicrich particles (Table 3 ). The molar $\mathrm{C}: \mathrm{N}$ varied seasonally between 8.9 and 10.6, typical for sinking detritus collected in deep sediment traps.

In the long term, the composition of settling particles in the deeper traps off Cape Blanc consisted of roughly $57 \%$ carbonate, ca. $30 \%$ lithogenic particles, $4 \%$ organic carbon, $0.5 \%$ nitrogen and $5 \%$ BSi (Fig. 4). BSi contained mostly a mixture of coastal and open-ocean diatoms (Romero et al. 1999, 2002, and unpublished data). The BSi flux pattern (Fig. 6) was influenced by switches from a positive to a negative NAO index which were reflected in decreasing winter fluxes, e.g. from 1989 to 1991,1995 to 1996 and 2007 to 2010 . From 2001 through 2006, NAO variability was rather low and the index was around zero or slightly negative (Fig. 6c; Table 4). Nevertheless, BSi fluxes varied considerably and showed episodic peaks in the summer seasons 2001, 2002 and 2003 (Fig. 6a, b). BSi flux was high and showed positive anomalies in 2005, except for spring 2005 (Fig. 6a, b; Table 4).

The general flux pattern of BSi (Fig. 6a, b) with values from almost zero to $1.91 \mathrm{~g} \mathrm{~m}^{-2}$ did not match the SeaWiFS ocean colour time series trend which showed an overall decrease in chlorophyll from 1997 to 2010 (Fig. 6d). The or- 


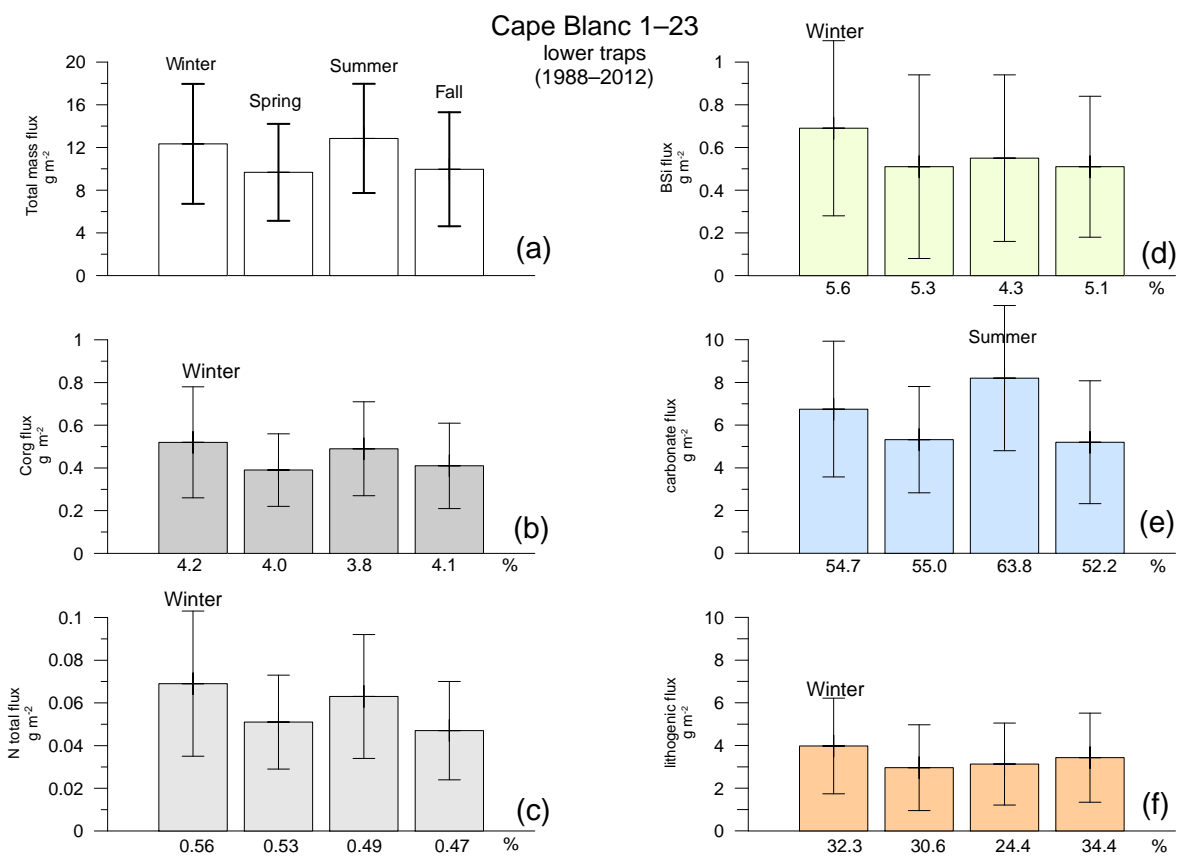

Figure 4. Seasonal means of major bulk fluxes of the lower traps only (a total, b organic carbon, $\mathbf{c}$ nitrogen, $\mathbf{d}$ biogenic silica $(=\mathrm{BSi})$, e carbonate, and $\mathbf{f}$ lithogenic $=$ mineral dust) and the respective standard deviations (1SD), which reflect interannual variability. Relative contributions $(\%)$ of $\mathrm{BSi}$, organic carbon, nitrogen, carbonate and lithogenic materials to total mass in the respective seasons are indicated by numbers below the bars.

Table 3. Correlation coefficients between organic carbon flux and major bulk flux components for the four different seasons (lower trap data only). Number of data points $(N)$ and the slopes $(s)$ for the regression lines are given as well. Statistically significant values for $R^{2}$ at a $99.9 \%$ confidence level are indicated in bold.

\begin{tabular}{lrrrr}
\hline Organic carbon & Winter & Spring & Summer & Autumn \\
\hline Nitrogen & $\mathbf{0 . 9 6}$ & $\mathbf{0 . 9 3}$ & $\mathbf{0 . 9 2}$ & $\mathbf{0 . 9 3}$ \\
& $N=16$ & $N=19$ & $N=19$ & $N=18$ \\
& $s=0.13$ & $s=0.12$ & $s=0.12$ & $s=0.11$ \\
\hline BSi & $\mathbf{0 . 7 0}$ & $\mathbf{0 . 4 6}$ & $\mathbf{0 . 6 3}$ & $\mathbf{0 . 7 5}$ \\
& $N=16$ & $N=19$ & $N=19$ & $N=18$ \\
& $s=1.3$ & $s=1.7$ & $s=1.4$ & $s=1.4$ \\
\hline Carbonate & $\mathbf{0 . 5 6}$ & $\mathbf{0 . 5 6}$ & 0.16 & $\mathbf{0 . 8 2}$ \\
& $N=15$ & $N=19$ & $N=19$ & $N=18$ \\
& $s=8.9$ & $s=10.9$ & $s=6.0$ & $s=13.2$ \\
\hline Lithogenic & $\mathbf{0 . 6 3}$ & $\mathbf{0 . 5 3}$ & 0.43 & $\mathbf{0 . 6 7}$ \\
(=mineral dust) & $N=16$ & $N=19$ & $N=19$ & $N=18$ \\
& $s=6.9$ & $s=8.5$ & $s=5.6$ & $s=8.6$ \\
\hline & & & &
\end{tabular}

ganic carbon flux pattern (not shown, values from almost zero to $1.1 \mathrm{~g} \mathrm{~m}^{-2}$ ) did not follow the ocean colour data from MODIS/SeaWiFS either. Peak chlorophyll values were observed mostly during spring, except in 1998 (autumn maximum) and 2007 (summer maximum). The MODIS ocean colour values generally mimicked the SeaWiFS pattern, except for the discrepancy in summer 2010 (Fig. 6d).

\section{Discussion}

\subsection{Particle transport processes in the water column}

Mass fluxes and particle transport processes off Cape Blanc (Mauritania) have been described by summarising articles of Fischer et al. (2009b) and Karakas et al. (2006). Common flux patterns were the increase of fluxes in late winterspring and late summer of all components at both trap levels. This matched the seasonal intensification of coastal upwelling (e.g. Meunier et al., 2012) due to wind forcing and a stronger offshore streaming of the Cape Blanc filament (e.g. Fischer et al., 2009b). The increase of fluxes in late summer to autumn was mostly due to enhanced biogenic carbonate sedimentation (Fig. 4e), associated with the northward flowing warm MC, coming from tropical regions (Mittelstaedt, 1991). In the Canary Current upwelling system, which is dominated by carbonate producers, particle settling rates are rather high (around $300 \mathrm{~m} \mathrm{~d}^{-1}$ ), compared to EBUEs dominated by BSi sedimentation (Fischer and Karakas, 2009; Fischer et al., 2009a). As suggested by Fischer et al. (2009a), the relatively high organic carbon flux in the deep ocean off NW Africa may be due to the high availability of mineral ballast, i.e. from coccolithophorids and fine-grained mineral 
Table 4. Summary of important flux changes between 1988 and 2012 which are related to large-scale climate modes such as NAO and ENSO. The record is divided into six major periods, including the outstanding year 2005 (see text).

\begin{tabular}{|c|c|c|c|c|c|c|}
\hline Period/years & 1988-1991 & $\begin{array}{l}\text { 1997-1999 } \\
\text { El Niño - } \\
\text { La Niña }\end{array}$ & $2001-2005 / 6$ & 2005 & $2007-2010$ & 2010-2012 \\
\hline \multicolumn{7}{|l|}{ FORCING } \\
\hline NAO & decreasing & increasing & $\begin{array}{l}\text { negative or } \\
\text { neutral }\end{array}$ & neutral & decreasing & increasing \\
\hline ENSO & & $\begin{array}{l}\text { strongest } \\
\text { ENSO }\end{array}$ & weak ENSOs & neutral & & \\
\hline \multicolumn{7}{|l|}{ FLUX RESPONSE } \\
\hline Carbonate & $\begin{array}{l}\text { decreasing } \\
\text { decreasing }\end{array}$ & $\begin{array}{l}\text { first } \\
\text { decreasing, } \\
\text { then increasing } \\
\text { generally high, } \\
\text { pteropod peaks }\end{array}$ & $\begin{array}{l}\text { episodic peaks } \\
\text { major episodic } \\
\text { pteropod peaks }\end{array}$ & $\begin{array}{l}\text { High throughout, } \\
\text { except spring }\end{array}$ & decreasing & increasing \\
\hline Lithogenic (dust) & decreasing & $\begin{array}{l}\text { first decreasing, } \\
\text { then increasing }\end{array}$ & & $\begin{array}{l}\text { high throughout, } \\
\text { except spring }\end{array}$ & decreasing & increasing \\
\hline
\end{tabular}

dust (Iversen et al., 2010; Iversen and Ploug, 2010; Ploug et al., 2008). Direct evidence for the influence of the deposition of dust particles on the settling rates of larger particles and the flux attenuation in the epi- and mesopelagic has been found on short timescales, i.e. days. This was observed during a severe dust outbreak in January 2012 (Iversen, unpublished observations) by deploying drifting traps before and after the dust outbreak (Fig. 8a, insert image).

\subsection{Influence of the NAO on biogenic silica sedimentation}

The NAO both affects coastal upwelling and productivity off Mauritania through wind forcing (upwelling) and dust/nutrient supply (Chiapello et al., 2005), mainly during winter (DJFM) (Goudie and Middleton, 2001; Cropper et al., 2014). Indeed, we observed an increase of both the winter NAO index and associated winter BSi fluxes (Figs. 6, $7 \mathrm{a}$ ), the latter known to be indicative of coastal upwelling strength and productivity. When plotting winter BSi fluxes versus the Azores pressure alone (DJFM Ponta Delgada SLP, 1989-2002), the relationship improves slightly $\left(R^{2}=0.19\right.$ $N=11$, not shown) but remains statistically insignificant. Since upwelling is wind-driven and large-scale wind patterns in the study area are positively correlated to NAO variability (Fig. 3a), a close linkage between a positive (negative) NAO and higher (lower) BSi fluxes can be expected. Organic carbon flux showed less correspondence to the winter NAO index (not shown). No clear relationship can be seen between the winter (DJFM) NAO index and BSi and organic carbon fluxes later in spring, if we consider a time delay of a few weeks between wind forcing of coastal upwelling, high chlorophyll standing stock, particle formation and sedimen- tation and, finally, the documentation of increasing fluxes in the deep traps in spring.

From 2001 to 2006 when the winter NAO index became close to zero (Fig. 6c), the BSi flux showed rather unusual (episodic) peaks either in summer, autumn or in winter 20042005 (Fig. 6a, b). This suggests increasing coastal upwelling in summer and autumn (e.g. Cropper et al., 2014) and/or a strengthening of the northward flowing and warmer MC, combined with an enhanced supply of a nutrient- and $\mathrm{Si}$ richer source water (SACW instead of NACW). We favour the latter scenario as there is evidence of unusual warm surface water conditions (SST anomalies of $+3^{\circ} \mathrm{C}$ ) related to weak trade wind intensity between 2002 and 2004 (Zeeberg et al., 2008; Alheit et al., 2014). These conditions might have led to a stronger influence of the northward flowing $\mathrm{MC}$ and the silicate-richer SACW which mixes into the Cape Blanc upwelling filament and, thus, contributed to higher BSi productivity and sedimentation. Such a scenario was proposed by Romero et al. (2008) to explain the extraordinary high content of BSi in Late Quaternary sediments deposited off Cape Blanc during Heinrich Event 1 and Younger Dryas following the Last Glacial Maximum.

The 2004-2005 winter BSi flux clearly falls off the regression line of winter BSi flux versus the winter NAO index (Fig. 7a). Exceptional conditions in 2005 are also indicated when plotting the area with high chlorophyll $(>1 \mathrm{mg}$ $\mathrm{Chl} a \mathrm{~m}^{-3}$ ) covered by the Cape Blanc filament (Fischer et al., 2009b) versus the BSi fluxes (Fig. 7b). In general, a larger (smaller) Cape Blanc filament area has been associated with higher (lower) BSi fluxes (Fig. 7b) and also with higher total mass fluxes (not shown). However, in winter of 2004-2005 (a relatively cold season with negative SST anomalies), the 


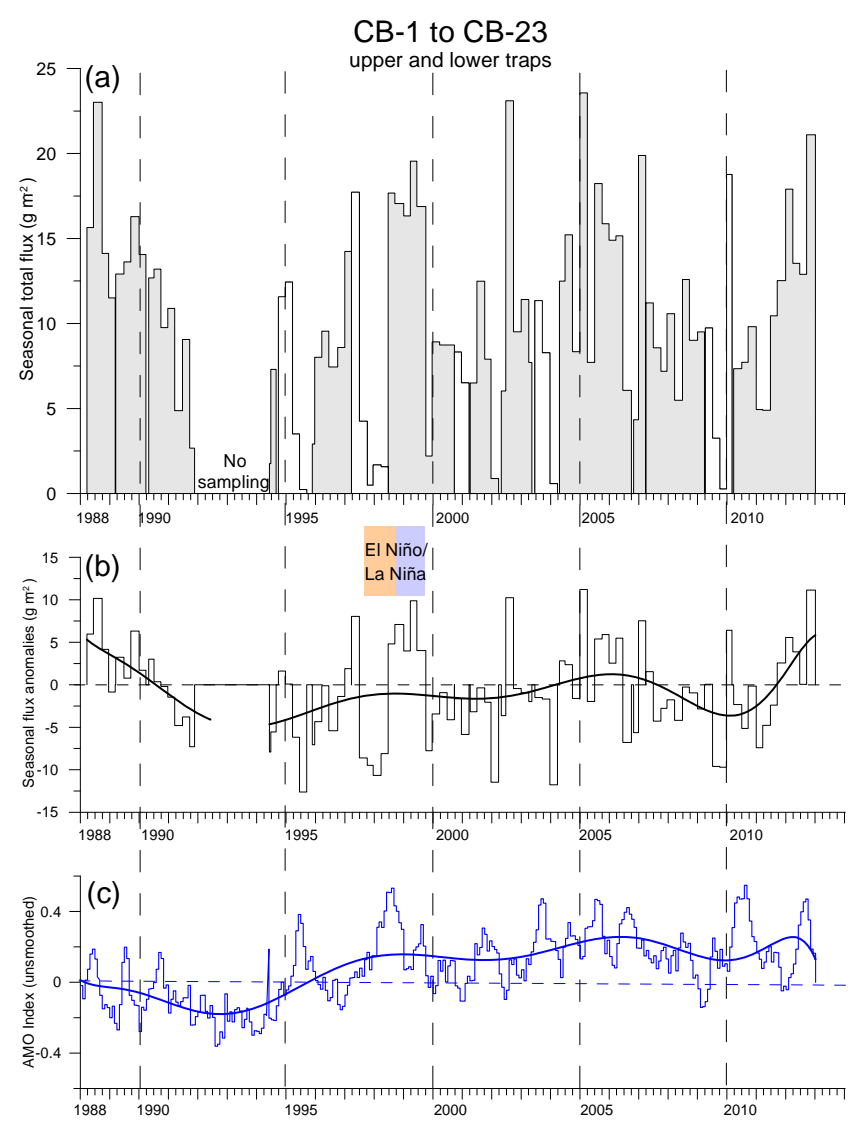

Figure 5. (a) Total mass fluxes of the lower traps (grey-shaded). Gaps were filled with upper trap data (light grey bars). Deviations of the seasonal total mass fluxes from the long-term seasonal means (anomalies), fitted with a 9-order polynomial (b). (c) Atlantic Multidecadal Oscillation (AMO) Index based on monthly SST fitted with a 9th-order polynomial fit (dashed blue line). The strong ENSO cycle 1997-1999 with a warm El Niño and a cold La Niña phase is indicated.

filament area was smaller and chlorophyll standing stock was lower (Figs. 6d, 7b). Nevertheless, BSi fluxes were the highest of the entire record. The seasonal variability of chlorophyll from the entire SeaWiFS record (1997-2010, Fig. 6d) indicates no relationship between the chlorophyll standing stock and deep ocean BSi flux (or organic carbon flux, not shown). These observations point to additional regulators for organic carbon and BSi export to the deep sea. Ocean colour imagery even revealed a decreasing trend from 1997 to 2010 (Fig. 6d), which suggests a decrease in upwelling. This is not consistent with the "Bakun upwelling intensification hypothesis" (Bakun, 1990) nor with studies from Kahru and Mitchell (2008). Throughout 2005, however, the positive BSi flux anomalies corresponded well with positive dust flux anomalies (Figs. 6b, 8b). As seen from Aerosol Optical Thickness (AOT, Fig. 8c), dust availability was rather high in 2005 and corresponded to high dust sedimentation in summer and autumn 2005 (Fig. 8; see Sect. 5.3). We suggest, there-

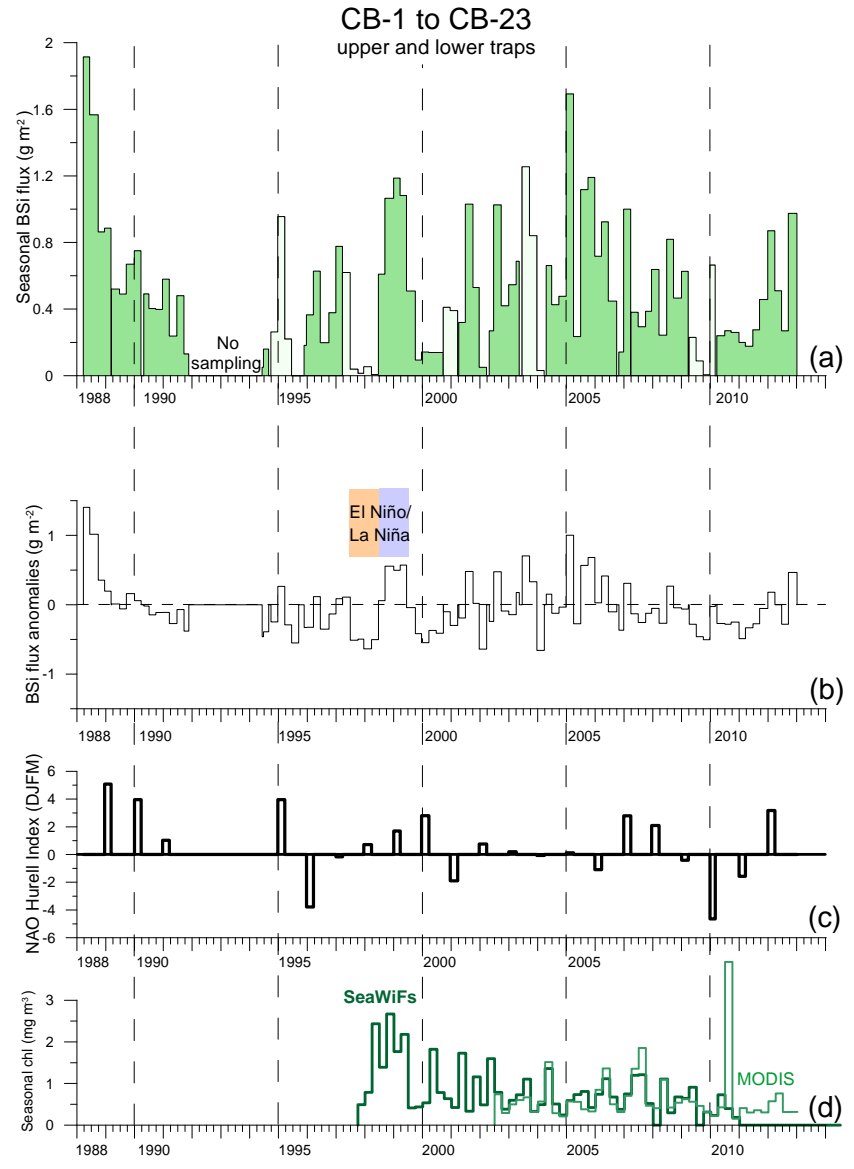

Figure 6. (a) Seasonal flux of biogenic silica (BSi, green) with gaps filled from the upper trap data (light green bars). Deviations of the long-term seasonal means (anomalies, b). (c) The NAO Hurrell index (DJFM). (d) Seasonal chlorophyll concentration both from the MODIS (light green) and the SeaWiFS (dark green) sensors at $9 \mathrm{~km}$ resolution. Note that high chlorophyll biomass generally occurs in spring but sometimes in summer/autumn as well (e.g. in 1998, 2007). SeaWiFS chlorophyll reveals a decreasing trend from 1997-2010, not mimicked in any flux data. The strong ENSO cycle 1997-1999 with a warm El Niño and a cold La Niña phase is indicated.

fore, that the linear relationship between the NAO index and BSi fluxes may be biased in years of anomalous dust input into the surface ocean.

\subsection{Interaction between mineral dust and the biological pump}

Fischer and Karakas (2009) stated that particle settling rates and organic carbon fluxes in the Canary Current system were unusually high compared to other EBUEs. This was mainly attributed to particle loading by dust particles (see also Fischer et al., 2009a, b; Iversen et al., 2010). BSi and lithogenic (mineral dust) fluxes point to a close linear relationship ( $R^{2}=0.78, N=21$, Fig. 9a) mainly in winter where 

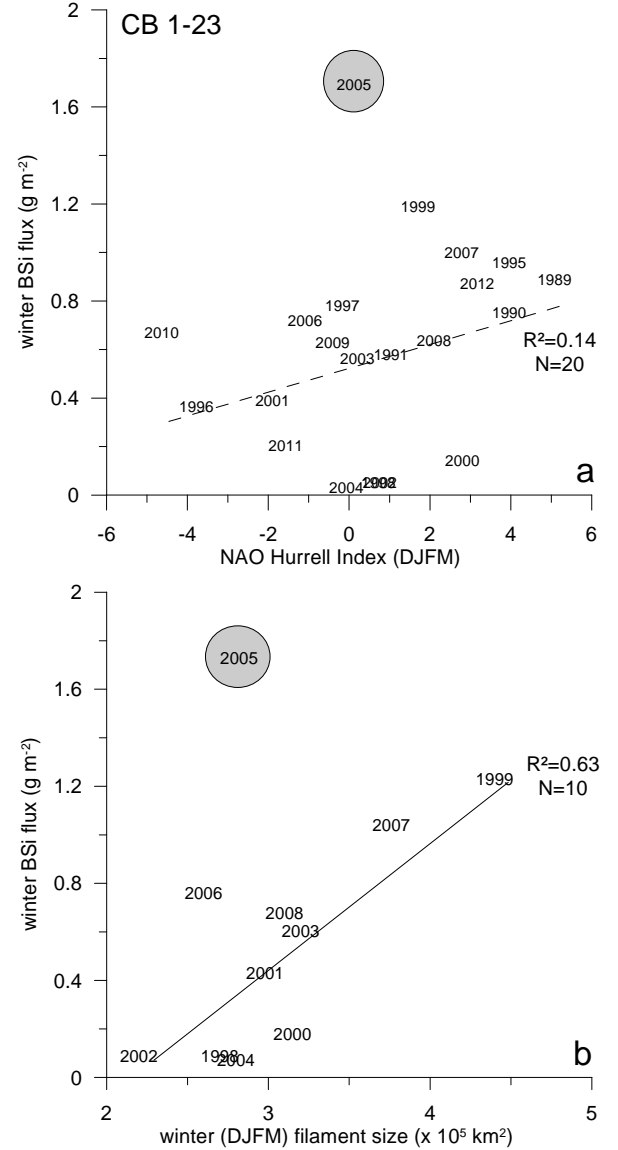

Figure 7. (a) The NAO Hurrell index (DJFM, Hurrell, 1995) plotted against winter BSi fluxes from Fig. 6. Note the increase of BSi with increasing NAO index. However, the relationship is weak due to unusual sedimentation events in the years 1998-1999, 2002, 2004, and, in particular in 2005. When omitting the data point from 2005, the correlation coefficient increases, but remains low $\left(R^{2}=0.14\right.$, $N=20$ ). Upper trap flux data from winter 1998 and 2004 may be too low as the filament with elevated chlorophyll was small and the particles did not reach the upper trap (see text). Omitting these two data point would slightly improve the relationship. (b) The size of the Cape Blanc filament (Fischer et al., 2009b) during winter months (DJFM) versus winter BSi fluxes shows higher fluxes with larger filament size. When omitting the BSi flux from winter 2005, a statistically significant relationship between filament size and fluxes is obtained $\left(R^{2}=0.63, N=10\right)$. Years given in the figure denote the respective winter seasons (e.g. 1999= December 1998March 1999).

dust availability and deposition is high (Goudie and Middleton, 2001), but not in summer $\left(R^{2}=0.56, N=23\right.$, Fig. 9b). High supply of dust into the surface ocean is often associated with dry conditions in the Sahel/Sahara in the previous year (Engelstaedter et al., 2006; Prospero and Lamb, 2003; Moulin and Chiapello, 2004). Indeed, the interval 2002-2004 in particular is known to have been much warmer and drier during summer/autumn on land and in the ocean (Zeeberg

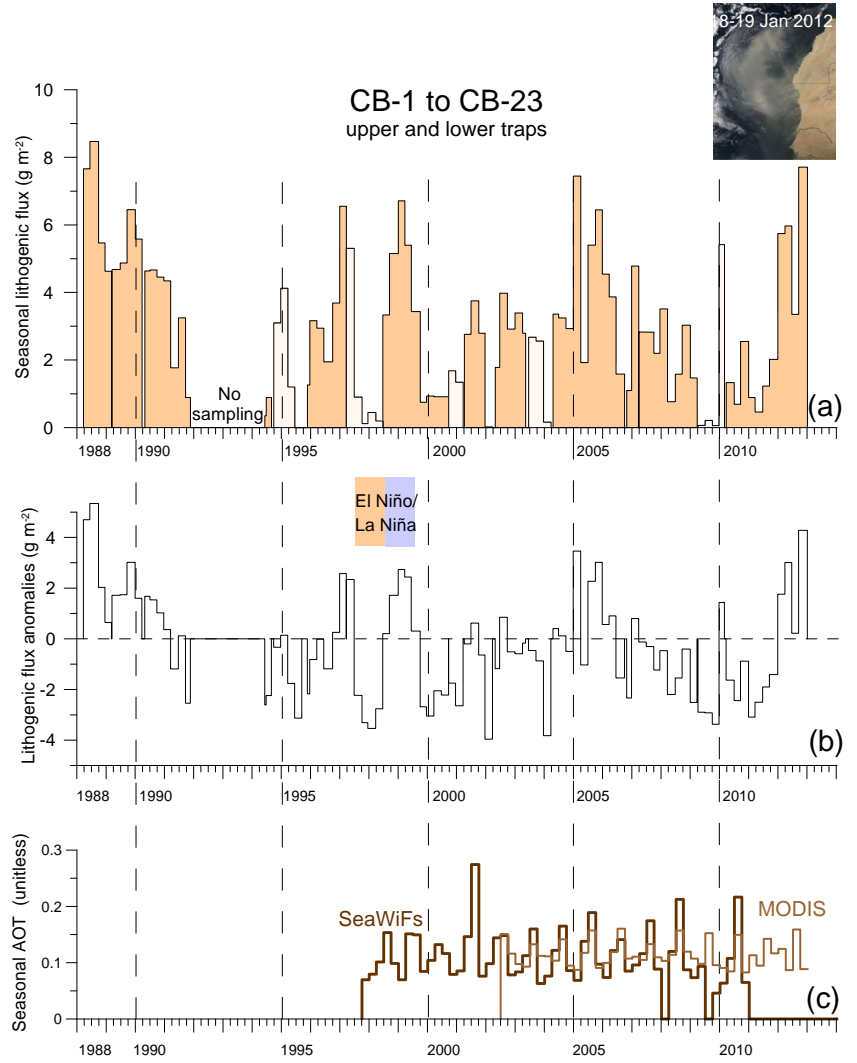

Figure 8. (a) Seasonal flux of lithogenic (=mineral dust) particles (orange) with gaps filled from the upper trap data (light orange bars). Deviations from the long-term seasonal means (anomalies, b). Note the large positive anomalies with longer duration in 1988-1989, 1997-2000 and 2005-2006. From about 2000 to 2004 2005, lithogenic fluxes remain rather low. In 2005, dust sedimentation and BSi flux (Fig. 6b) were high throughout the year. (c) The AOT from the SeaWiFS (brown) and MODIS (light brown) sensors shows repeatedly high values in summer, but not in winter when dust sedimentation is highest in the study area. A typical short-term (2-day) dust storm in January 2012 is shown as insert in the upper right. The strong ENSO cycle 1997-1999 with a warm El Niño and a cold La Niña phase is indicated.

et al., 2008; Alheit et al., 2014). These conditions might have allowed the later wind-induced mobilization of larger amounts of dust particles into the atmosphere and led to a dust-enriched atmosphere during the entire year 2005, combined with elevated deep ocean mass fluxes.

Typically, highest dust flux off Cape Blanc occurs in winter (Fig. 8) whereas part of the summer dust load is transported further westward and deposited in the Caribbean Sea (Goudie and Middleton, 2001; Prospero and Lamb, 2003). However, the rainfall pattern exhibits elevated precipitation in summer and autumn 2005 when the tropical rainbelt was far north; this might have led to unusual wet deposition of dust in summer over our study site (Friese et al., 2016). As shown earlier, BSi fluxes show positive anomalies in sum- 

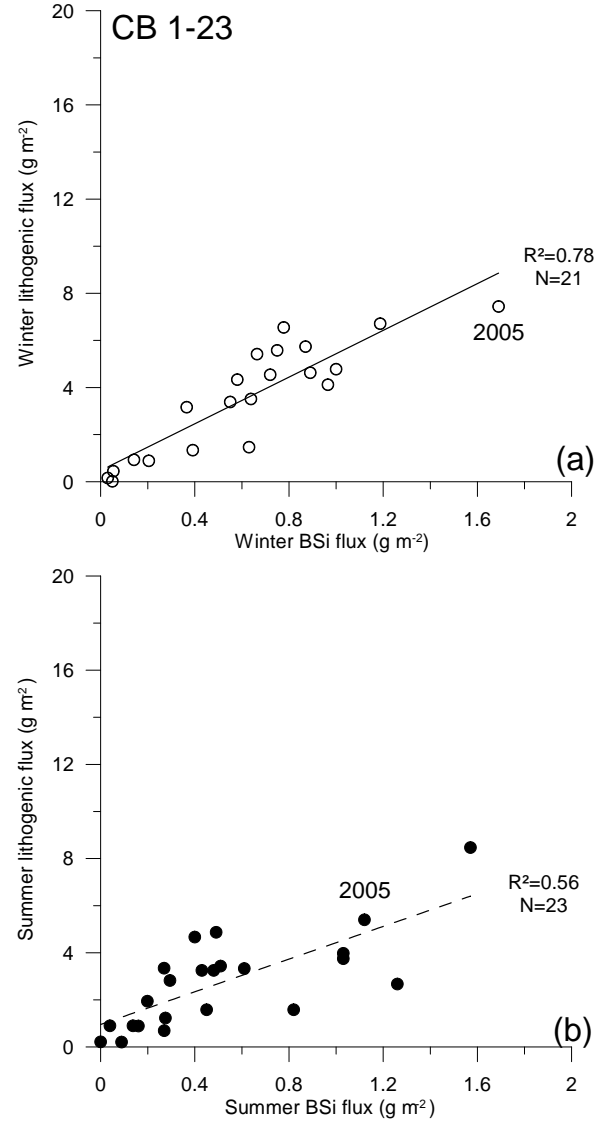

Figure 9. Relationships between BSi and lithogenic (=mineral dust) fluxes for the winter (a) and summer (b) seasons. Note the high correspondence in winter $\left(R^{2}=0.78, N=21\right)$; a lower coefficient is found for the summer season. During the outstanding year of 2005 (see Fig. 7), both points for winter and summer are close to the linear regression line.

mer and autumn 2005 (Fig. 6b), pointing to a stronger dustinfluenced biological pump.

In contrast to $\mathrm{BSi}$, winter sedimentation of mineral dust did not show any common trend with the winter NAO index (not shown). Using satellite-derived AOT, Chiapello et al. (2005) suggested a close relationship of atmospheric dust content and the NAO index. High AOT, however, does not necessarily correspond with high dust deposition into the ocean. Moreover, dust deposition into the ocean surface does not unavoidably and directly result in particle export and transfer to the deep ocean. Dust deposition is not only controlled by wind strength and direction in the trap area but also by source region conditions and precipitation over the trap site. Consequently, considering the NAO as the only controlling factor for dust deposition and sedimentation even if the correlation between SLP (and thus winds) and NAO is strong in the study area (Fig. 3a), would be an oversimplification.

Another explanation for the missing relationship could be that fine-grained dust accumulates in surface waters until the

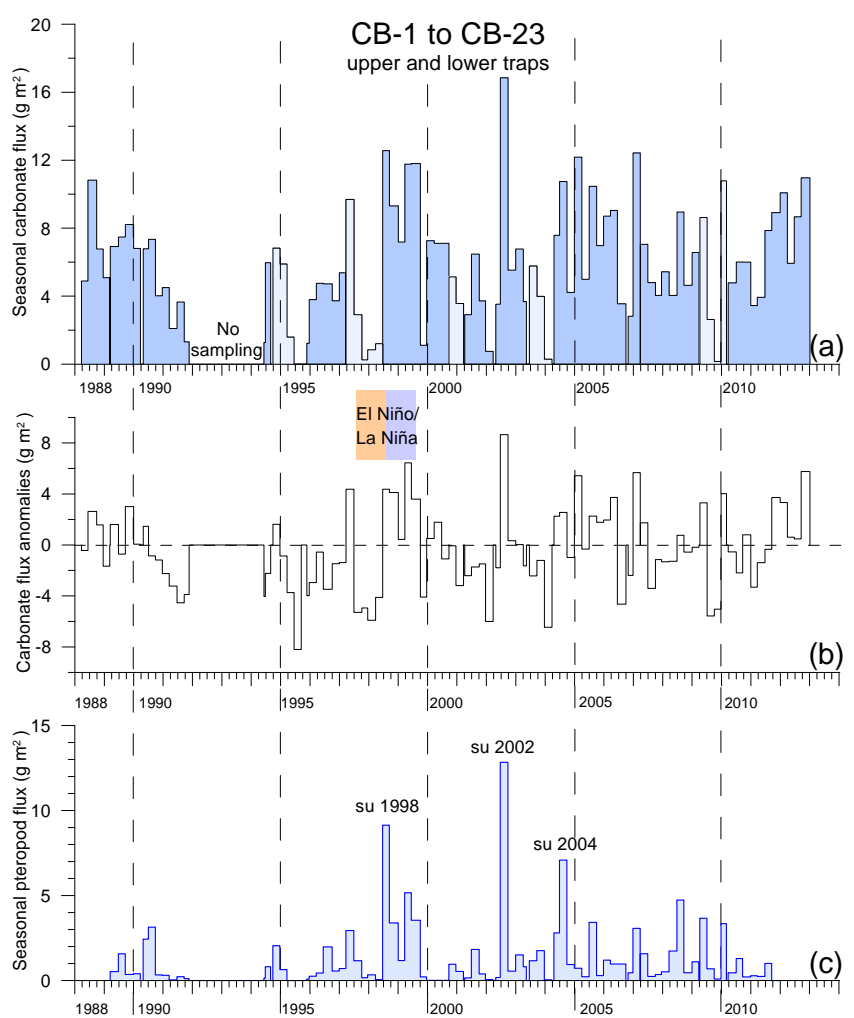

Figure 10. (a) Seasonal flux of total carbonate (blue) with gaps filled from the upper trap data (light blue bars). Deviations from the long-term seasonal means (anomalies, b). (c) Seasonal flux of pteropods. During the strongest ENSO cycle 1997-2000, longer periods of low and high carbonate fluxes occurred. Note the episodic sedimentation pattern of pteropods with maxima e.g. in summer 1998, 2002 and 2004. The strong ENSO cycle 1997-1999 with a warm El Niño and a cold La Niña phase is indicated.

biological pump produces sufficient organic particles to allow the formation of larger particles which then settle into the deep ocean (Bory et al., 2002; Ternon et al., 2010; Nowald et al., 2015). Cape Blanc dust particles have predominant grain sizes between 10 and $20 \mu \mathrm{m}$ (Ratmeyer et al., 1999a, b; Friese et al., 2016) and, thus, would sink too slowly to build a deep ocean flux signal. We propose that only the close coupling between the organic carbon pump, dust particles and the formation of dense and larger particles led to elevated export and sedimentation (Bory et al., 2002; Fischer et al., 2009a; Fischer and Karakas, 2009). Thunell et al. (2007) found that organic carbon fluxes strongly correlated with mineral fluxes in other upwelling-dominated continental margin time series such as the Santa Barbara Basin located within the California Current System. However, the detailed processes and interaction between different groups of phytoplankton and types of ballast minerals (e.g. quartz versus clay minerals etc.) are largely unknown and need clarification. Laboratory experiments with different ballast minerals (e.g. Iversen and Roberts, 2015) and measurements of 
organic carbon respiration and particle settling rates suggest a significant influence of ballast minerals on particle settling rates, carbon respiration and flux (Ploug et al., 2008; Iversen and Ploug, 2010). In a time series study with optical measurements, addressing particle characteristics (e.g. sizes) and using fluxes at the nearby eutrophic sediment trap off Cape Blanc $\left(\mathrm{CB}_{\mathrm{eu}}\right)$, Nowald et al. (2015) suggested an influence of dust outbreaks on particle sedimentation down to $1200 \mathrm{~m}$. Interestingly, settling organic-rich particles off Cape Blanc were only around $1 \mathrm{~mm}$ in size during the two-year deployment from 2008 to 2010 (Nowald et al., 2015). Higher fluxes were mostly attributed to higher numbers of small particles rather than to larger particle sizes during blooms in the Cape Blanc area (Nowald et al., 2015).

\subsection{Carbonate fluxes and potential ENSO teleconnections}

Deep ocean total mass and carbonate fluxes (Figs. 5, 10) showed elevated values over more than a year from summer 1998 to autumn 1999 during a La Niña event, whereas BSi and dust fluxes showed positive anomalies of shorter duration (autumn 1998 to spring 1999) (Fig. 6b). Investigating SeaWiFS-derived ocean colour in the Mauritanian upwelling region, Pradhan et al. (2006) obtained a link between the multivariate ENSO index, the strength of upwelling and the chlorophyll standing stock ( $250 \%$ increase) during the 1998-1999 La Niña. They also observed that during the mature La Niña phase in the Pacific Ocean, NW African trade winds increased in winter-spring. Coincidentally, Helmke et al. (2005) obtained a more than doubling of the deep ocean organic carbon fluxes in autumn 1998 to summer 1999 during the major La Niña phase.

We obtained positive carbonate flux anomalies with a longer duration in summer 1998 to autumn 1999 and summer 2005 to spring 2006 (Fig. 10b). During autumn 1998 (La Niña phase), the area of the Cape Blanc filament was unusually large compared with autumn 1997 (El Niño phase) (Fig. 1d, e). The contribution of major carbonate producers to total carbonate flux varied both on seasonal and interannual timescales (Fischer et al., 2009a). These authors observed that nannofossils contributed almost $95 \%$ to carbonate sedimentation in 1991 (a relatively cold year) but only $64 \%$ in 1989 (a relatively warm year). In the long term, nannofossils showed a rather low seasonality. Among the calcareous microorganisms, pteropods had the strongest seasonal signal which did not quite match the pattern of carbonate flux (Fig. 10a, c). As previously observed by Kalberer et al. (1993), a possible explanation is the high pteropod flux (mostly Limacina inflata) in summer 1989 due to unusual high SSTs. In our record, we found distinct pulses of pteropods in the summer seasons of 1998, 2002 and 2004 (Fig. 10c). In particular, the peaks in 2002 and 2004 can be attributed to anomalously warm conditions in the study area (Zeeberg et al., 2008; Alheit et al., 2014). Here, a pe- riod of near-neutral NAO together with an almost permanent El Niño phase during 2002-2004 might have acted in concert towards weakening trade winds which allows a stronger influence of the warm and northward flowing MC, supplying high amounts of pteropods from tropical waters. In summary, ENSO may impact differently on different flux components. Whereas an increase in pteropod fluxes is found during the El Niño phase, La Niña induces an increase in total carbonate flux.

\subsection{Decadal variability and potential trends in mass fluxes}

Our records allow a first estimate of deep-ocean mass flux variations beyond seasonal-to-interannual timescales. The "Bakun upwelling intensification hypothesis" (Bakun, 1990) has been supported by other studies using long-term SSTs, wind stress records or upwelling indices (e.g. Cropper et al., 2014; Narayan et al., 2010). Kahru and Mitchell (2008) applied satellite derived chlorophyll time series from SeaWiFS to conclude that chlorophyll standing stock in major upwelling regions of the world oceans had increased since September 1997. However, these records are rather short (1997-2006) and started in an unusual period with the strongest ENSO ever reported (1997-1998). In our record, no long-term trend in any mass flux component from 1988 through 2012 is seen, which would indicate a long term increase or decrease in the strength of coastal upwelling off Cape Blanc. The 1997-2010 chlorophyll time series from SeaWiFS (Fig. 6d) shows a decreasing standing stock, which might indicate a decrease in the strength of coastal upwelling in the Cape Blanc area. The upwelling indices used by Cropper et al. (2014) showed a decreasing trend from 1980-2013 for the Mauritanian-Senegalese upwelling zone $\left(12-19^{\circ} \mathrm{N}\right)$, while observing some interdecadal variability. All these observations together point to regional differences within the upwelling system along the NW African coast (Cropper et al., 2014) with respect to long-term trends in upwelling and chlorophyll standing stock. According to these findings, only the southernmost weak permanent upwelling zone (21$26^{\circ} \mathrm{N}$ ) would be in concert with the "Bakun upwelling intensification hypothesis". Another implication is that trends detected from near-surface data/indices are not necessarily reflected in changes of deep-ocean mass fluxes and organic carbon sequestration. No evidence of decreasing dust fluxes from the Sahara/Sahel is seen in our lithogenic (dust) flux record (Fig. 8a), which might indicate "Saharan greening" and reduced dust plumes during the past 2 decades (Zhao et al., 2010; Fontaine et al. 2011). Thus, mass flux patterns might be partly independent from chlorophyll standing stock or the size of the Cape Blanc filament.

Long-term model simulations under present-climate boundary conditions allow to study the linkages within the climate system on decadal timescales and beyond. Climate modes such as the AMO are operating in this frequency 
band, and a correlation between large-scale patterns of SLP and North Atlantic SST (AMO) index (both lowpass-filtered for periods above 10 years, Fig. 3c) suggests that even on these long timescales, climate modes such as the AMO might impact on climate variables such as SLP, SST and wind patterns, specifically through a weakening of the trade winds over the eastern Atlantic during the AMO warm phase (Fig. 3c). This response of the winds to low-frequency SST variations is consistent with earlier findings on interdecadal Atlantic SST variability (Kushnir, 1994; Alexander et al., 2014), and could influence the main characteristics of particle fluxes at our study site (Fig. 5). However, as current particle flux records from sediment traps only cover a few decades and cannot resolve AMO cycles with statistical robustness, continuation of trap experiments are essential to capture all relevant timescale variations. They will help to understand modern particle settling rates and the interpretation of marine sediment records used in paleoclimate reconstructions.

\section{Summary and conclusions}

In our study, we presented a sediment trap record from the Eastern Boundary Upwelling Ecosystem area off Cape Blanc (Mauritania) for the period 1988-2012. Our major findings can be summarized as follows (also see Table 4):

1. Winter BSi fluxes showed a trend of increasing values with an increasing NAO Hurrell Index and the increasing Azores SLP as well. However, both relationships are statistically insignificant.

2. Episodic BSi flux peaks occurred between 2000 and 2005 when the NAO was neutral or negative. Dust outbreaks, followed by dry (winter) and wet (summer) deposition (e.g. in 2005) into the ocean, might have modified the efficiency of the biological pump and resulted in increased downward fluxes (e.g. of BSi or organic carbon) which were not related to any large-scale forcings.

3. Only the extreme 1997-1999 ENSO was documented clearly in the record, with low fluxes for almost a year during the warm El Niño phase, followed by high fluxes of almost a year during the following cold La Niña phase.

4. In addition to episodic BSi fluxes, episodic peaks of pteropods occurred in the summers 2002 and 2004 (Fig. 10c, Table 4). This occurred during a neutral NAO phase and weakening trade winds, allowing a stronger influence from tropical surface waters from the south via the Mauritanian Current (MC) and an entrainment of Si-richer subsurface waters.

5. Teleconnections from ENSO and the NAO may have opposite effects on the NW African upwelling (Fig. 3) with potential implications for deep ocean mass fluxes.
In particular, ENSO might confound the relationship between the NAO and BSi fluxes.

6. Fluxes from 1988-2012 point to a long-term decadal variability, probably related to the Atlantic Multidecadal Oscillation. However, the time series record is too short to reproduce AMO cycles with statistical robustness.

7. No long-term trend of any flux component was observed in the Mauritanian upwelling off Cape Blanc and therefore does not support the "Bakun upwelling intensification hypothesis" (Bakun, 1990; Cropper et al., 2014).

8. We found no evidence of an increasing/decreasing supply of dust and its deposition off Mauritania between 1988 and 2012.

The long-term flux record allows insights into the influences of major climatic oscillations such as the NAO and on particle export and transfer of particles to the deep ocean and might help to evaluate how the ecosystem off Mauritania could develop in the future. We have some indications that the relationships between major Northern Hemisphere climate oscillations (e.g. the NAO) and deep ocean mass fluxes are weakened by short-term ecosystem perturbations, e.g. due to dust outbreaks, the latter probably leading to episodic sedimentation pulses into the deep ocean. The complex processes of the interaction of non-biogenic particles (e.g. different minerals within dust, e.g. Iversen and Roberts, 2015) with organic materials produced by photosynthesis, aggregate formation and disintegration in the epi- and mesopelagic, particle characteristics (e.g. Nowald et al., 2015), settling rates and remineralization require further process studies, combined with laboratory experiments and different modelling approaches (e.g. particle (dis-) aggregation, Karakas et al., 2009).

Additionally, our record provides information on potential long-term changes or trends of mass fluxes which point to ecosystem changes or an intensification/weakening of the NW African upwelling system in the study area. Considering the present record of bulk fluxes of more than 2 decades, we have no indication of any long-term trend which might suggest a fundamental ecosystem change or a regime shift (stepwise change) in this important coastal upwelling ecosystem.

\section{Data availability}

Text data availalbility The flux data shown in the tables of the manuscript and the sediment trap metadata will be made available under: www.pangaea.de.

Author contributions. Gerhard Fischer prepared the ms with contributions from the co-authors. Oscar Romero investigated the diatom producers and contributed to the discussion, Ute Merkel contributed 
the model simulations and the analysis, Barbara Donner studied the carbonate producers, Morten Iversen and his group did the dust experiments and provided unpublished results/observations, Nico Nowald and Volker Ratmeyer performed the optical observations and analysis of particles, Götz Ruhland and Marco Klann designed the sediment trap experiments and analysed the sediment trap samples, Gerold Wefer planned the entire program and contributed to the discussion.

Acknowledgements. We are greatly indebted to the masters and crews of many expeditions (Table 1). Many thanks also go to the chief scientists of the expeditions for their support during the cruises and for the planning activities and cooperations. We also would like to thank the Mauritanian, Moroccan and German authorities for their help during the planning phases of the expeditions. This work was only possible because of the long-term funding by the Deutsche Forschungsgemeinschaft through the SFB 261 (The South Atlantic in the Late Quaternary: Reconstruction of Mass Budget and Current Systems, 1989-2001) and the Research Center Ocean Margins. During about the last decade, the study is supported by the Marum Excellence Cluster, "The Ocean in the Earth System". The model simulation done by Ute Merkel has been performed at the supercomputer of the Norddeutscher Verbund für Hoch- und Höchstleistungsrechnen (HLRN), Hannover, Germany. We thank the two anonymous reviewers for helpful, fair and constructive comments and the associate editor for handling the manuscript.

The article processing charges for this open-access publication were covered by the University of Bremen.

Edited by: J. Middelburg

\section{References}

Alexander, M. A., Kilbourne, K. H., and Nye, J. A.: Climate variability during warm and cold phases of the Atlantic Multidecadal Oscillation (AMO) 1871-2008, J. Marine Syst., 133, 14-26, 2014.

Alheit, J., Licandro, P., Coombs, S., Garcia, A., Giráldez, A., Santamaría, M. T. G., Slotte, A., and Tsikliras, A. C.: Atlantic Multidecadal Oscillation (AMO) modulates dynamics of small pelagic fishes and ecosystem regime shifts in the eastern North and Central Atlantic, J. Mar. Syst., 133, 88-102, 2014.

Arístegui, J., Barton, E. C., Álvarez-Salgado, X. A., Santos, A. M. P., Figueiras, F. G., Kifani, S., Hernández-León, S., Mason, E., Machú,E., and Demarcq, H.: Sub-regional ecosystem variability in the Canary Current upwelling, Prog. Oceanogr., 83, 33-48, 2009.

Armstrong, R. A., Lee, C., Hedges, J. I., Honjo, S., and Wakeham, S. G.: A new mechanistic model of organic carbon fluxes in the ocean based on the quantitative association of POC with ballast minerals, Deep-Sea Res. Pt. II, 49, 219-236, 2002.

Bakun, A.: Global climate change and intensification of coastal ocean upwelling, Science, 247, 198-201, 1990.

Barton, E. D., Arístegui, J., Tett, P., Cantón, M., García-Braun, J., Hernández-León, S., Nykjaer, L., Almeida, C., Almunia, J.,
Ballesteros, S., Basterretxea, G., Escánez, J., García-Weill, L., Hernández-Guerra, A., López-Laatzen, F., Molina, P., Montero, M. F ., Navarro-Pérez, E., Rodriguez, J. M., van Lenning, K., Vélez, H., and Wild, K.: Eastern Boundary of the North Atlantic: northwest Africa and Iberia, in: The Global Coastal Ocean, Vol. 11, edited by: Robinson, A. R. and Brink, K., John Wiley and Sons, New York, Chichester, Weinheim, Brisbane, Singapore, Toronto, 29-67, 1998.

Behrenfeld, M. J. and Falkowski, P. G.: Photosynthetic rates derived from satellite based chlorophyll concentration, Limnol. Oceanogr., 42, 1-20, 1997.

Behrenfeld, M. J., Randerson, J. T., McClain, C. R., Feldman, G. C., Los, S. O., Tucker, C. J., Falkowski, P., Field, C. B., Frouin, R., Esaias, W. E., Kolber, D. D., and Pollack, N. H.: Biospheric primary production during an ENSO transition, Science, 291, 25942597, 2001.

Bode, A., Alvarez-Ossorio, M. T., Cabanas, J. M., Miranda, A., and Varela, M.: Recent trends in plankton and upwelling intensity off Galicia (NW Spain), Prog. Oceanogr., 83, 342-350, 2009.

Bory, A. J. M. and Newton, P. P.: Transport of airborne lithogenic material down through the water column in two contrasting regions of the eastern subtropical North Atlantic Ocean, Global Biogeochem. Cy., 14, 297-315, 2000.

Bory, A., Dulac, F., Moulin, C., Chiapello, I., Newton, P. P., Guelle, W., Lambert, C. E., and Bergametti, G.: Atmospheric and oceanic dust fluxes in the northeastern tropical Atlantic ocean: how close a coupling?, Ann. Geophys., 20, 2067-2076, 2002.

Bressac, M., Guieu, C., Doxaran, D., Bourrin, F., Desboeufs, K., Leblond, N., and Ridame, C.: Quantification of the lithogenic carbon pump following a simulated dust-deposition event in large mesocosms, Biogeosciences, 11, 1007-1020, doi:10.5194/bg-11-1007-2014, 2014.

Brust, J., Schulz-Bull, D. E., Leipe, T., Chavagnac, V., and Waniek, J. J.: Descending particles: from the atmosphere to the deep ocean: A time series study in the subtropical NE Atlantic, Geophys. Res. Lett., 38, L06603. doi:10.1029/2010GL045399, 2011.

Buesseler, K. O., Antia, A. A., Chen, M., Fowler, S. W., Gardner, W. D., Gustafsson, O., Harada, K., Michaels, A. F., Rutgers van der Loeff, M., Sarin, M., Steinberg, D. K., and Trull, T.: An assessment of the use of sediment traps for estimating upper ocean particle fluxes, J. Mar. Res., 65, 345-416, 2007.

Carr, M.-E.: Estimation of potential productivity in Eastern Boundary Currents using remote sensing, Deep-Sea Res. Pt. I, 49, 5980, 2002.

Checkley Jr., D. M. and Barth, J. A.: Patterns and processes in the California Current Systems, Prog. Oceanogr., 83, 49-64, 2009.

Chiapello, I., Moulin, C., and Prospero, J. M.: Understanding the long-term variability of African dust transport across the Atlantic as recorded in both Barbados surface concentrations and large-scale Total Ozone Mapping Spectrometer (TOMS) optical thickness, J. Geophys. Res., 110, D18S10, doi:10.1029/2004JD005132, 2005.

Collins, W. D., Bitz, C. M., Blackmon, M. L. Bonan, G. B., Bretherton, C. S., Carton, J. A., Chang, P., Doney, S. C., Hack, J. J., Henderson, T. B., Kiehl, J. T., Large, W. G., McKenna, D. S., Santer, B. D., and Smith, R. D.: The Community Climate System Model Version (CCSM3), J. Climate, 19, 2122-2143, 2006. 
Cropper, T. E., Hanna, E., and Bigg, G. R.: Spatial and temporal seasonal trends in coastal upwelling off Northwest Africa, 19812012, Deep-Sea Res. Pt. II, 86, 94-111, 2014.

Diatta, S. and Fink, A. H.: Statistical relationship between remote climate indices and West African monsoon variability, Int. J. Climatol., 34, 3348-3367, 2014.

Ducklow, H. W., Doney, S. C., and Steinberg, D. K.: Contributions of long-term research and teim-sereis observations to marine ecology and biogeochemistry, Annu. Rev. Mar. Sci., 1, 279302, 2009.

Dunne, J. P., Sarmiento, J. L., and Gnanadesikan, A.: A synthesis of global particle export from the surface ocean and cycling through the ocean interior and on the seafloor, Global Biogeochem. Cy., 21, GB4006, doi:10.1029/2006GB002907, 2007.

Engelstaedter, S., Tegen I., and Washington, R.: North African dust emissions and transport, Earth Sci. Rev., 79, 73-100, 2006.

Feldman, G.: NASA/Goddard Flight Space Center, Ocean Color Web, http://oceancolor.gsfc.nasa.gov/cgi/13?ctg=Standard\&sen= A\&prd=CHL_chlor_a\&per $=$ SN\&date $=21$ Jun2002\&res $=$ $9 \mathrm{~km} \&$ num $=24,2015$.

Feldman, G.: NASA/Goddard Flight Space Center, Ocean Color Web, http://oceancolor.gsfc.nasa.gov/cgi/13/S19972641997354. L3m_SNAU_CHL_chlor_a_9km.png?, 2015.

Fischer, G. and Karakas, G.: Sinking rates and ballast composition of particles in the Atlantic Ocean: implications for the organic carbon fluxes to the deep ocean, Biogeosciences, 6, 85102, doi:10.5194/bg-6-85-2009, 2009.

Fischer, G. and Wefer, G.: Sampling, preparation and analysis of marine particulate matter, in: The Analysis and Characterization of Marine Particles, edited by: Hurd, D. C. and Spencer, D. W., Geophys. Monogr. Serie., 63, 391-397, 1991.

Fischer, G., Donner, B., Ratmeyer, V., Davenport, R., and Wefer, G.: Distinct year-to-year particle flux variations off Cape Blanc during 1988-1991: Relation to delta $\delta^{18}$ O-deduced sea-surface temperatures and trade winds, J. Mar. Res., 54, 73-98, 1996.

Fischer, G., Wefer, G., Romero, O., Dittert, N., Ratmeyer, V., and Donner, B.: Transfer of particles into the deep Atlantic and the global Ocean: control of nutrient supply and ballast production, in: The South Atlantic in the Late Quaternary: Reconstruction of material budget and current systems, edited by: Wefer, G., Mulitza, S., and Ratmeyer, V., Springer, Berlin, Heidelberg, New York, 21-46, 2003.

Fischer, G., Karakas, G., Blaas, M., Ratmeyer, V., Nowald, N., Schlitzer, R., Helmke, P., Davenport, R., Donner, B., Neuer, S., and Wefer, G.: Mineral ballast and particle settling rates in the coastal upwelling system off NW Africa and the South Atlantic, 98, 281-298, 2009a.

Fischer, G., Reuter, C., Karakas, G., Nowald, N., and Wefer, G.: Offshore advection of particles within the Cape Blanc filament, Mauritania: Results from observational and modelling studies, Prog. Oceanogr., 83, 322-330, 2009b.

Fischer, G., Neuer, S., Davenport, R., Romero, O., Ratmeyer, V., Donner, B., Freudenthal, T., Meggers, H., and Wefer, G.: The Northwest African Margin, in: Carbon and Nutrient Fluxes in Continental Margins: A Global Synthesis, edited by: Liu, K. K., Atkinson, L., Quinones, R., and Talaue-McManaus, L., IGBP Book Series, Springer, Berlin, 77-103, 2010.

Fontaine, B., Roucou, P., Gaetani, M., and Marteau, R.: Recent changes in precipitation, ITCZ convection and northern tropical circulation over North Africa (1979-2007), Int. J. Climatol., 31, 633-648, 2011.

Fréon, P., Barange, M., and Aristegui, J.: Eastern Boundary Upwelling Ecosystems: integrative and comparative approaches, Prog. Oceanogr., 83, 1-14, 2009.

Friese, C., van der Does, M., Merkel, U., Iversen, M., Fischer, G., and Stuut, J.-B.: Environmental factors controlling the seasonal variation in particle size of modern Saharan dust deposited offshore Cape, Blanc, Aeolian Res., in press, 2016.

Goudie, A. S. and Middleton, N. J.: Saharan dust storms: nature and consequences, Earth Sci. Rev., 56, 179-204, 2001.

Hedges, J. I., Baldock, J. A., Gelinas, Y., Lee, C., Peterson, M. L., and Wakeham, S. G.: The biochemical and elemental compositions of marine plankton: a NMR perspective, Mar. Chem., 78, 47-63, 2002.

Helmke, P., Romero, O., and Fischer, G.: Northwest African upwelling and its effect on off-shore organic carbon export to the deep sea, Global Biogeochem. Cy., 19, GB4015, doi:10.1029/2004GB002265, 2005.

Hsu, N. C., Gautam, R., Sayer, A. M., Bettenhausen, C., Li, C., Jeong, M. J., Tsay, S.-C., and Holben, B. N.: Global and regional trends of aerosol optical depth over land and ocean using SeaWiFS measurements from 1997 to 2010, Atmos. Chem. Phys., 12, 8037-8053, doi:10.5194/acp-12-8037-2012, 2012.

Hurrell, J. W.: NAO Index Data provided by the Climate Analysis Section, NCAR, Boulder, USA, Updated regularly, http://climatedataguide.ucar.edu/guidance/ hurrell-north-atlantic-oscillation-nao-index-station-based (last access: 01 January 2012), 1995.

Hurrell, J.: National Center for Atmospheric Research, NCAR/UCAR Climate Data Guide, https://climatedataguide.ucar.edu/climate-data/ hurrell-north-atlantic-oscillation-nao-index-station-based, 2015.

Ichoku, C.: NASA/Goddard Flight Space Center, NASA Earth Observatory, Global Maps, http://earthobservatory.nasa.gov/ GlobalMaps/?eocn=topnav\&eoci=globalmaps, 2015.

Iversen, M. H., and Ploug, H.: Ballast minerals and the sinking carbon flux in the ocean: carbon-specific respiration rates and sinking velocities of marine snow aggregates, Biogeosciences 7 , 2613-2624, doi:10.5194/bg-7-2613-2010, 2010.

Iversen, M. H. and Robert, M. L.: Ballasting effects of smectite on aggregate formation and export from a natural plankton community, Mar. Chem., 175, 18-27, 2015.

Iversen, M. H., Nowald, N., Ploug, H., Jackson, G. A., and Fischer, G.: High resolution profiles of vertical particulate organic matter export off Cape Blanc, Mauritania: degradation processes and ballasting effects, Deep-Sea Res. Pt. I, 57, 771-784, 2010.

Jickells, T. D., An, Z. S., Andersen, K. K., Baker, A. R., Bergametti, G., Brooks, N., Cao, J. J., Boyd, P. W., Duce, R. A., Hunter, K. A., Kawahata, H., Kubilay, N., laRoche, J., Liss, P. S., Mahowald, N., Prospero, J. M., Ridgwell, A. J., Tegen, I., and Torres, R.: Global iron connections between desert dust, ocean biogeochemistry, and climate, Science, 308, 67-71, 2005.

Kahru, M. and Mitchell, B. G.: Ocean colour reveals increased blooms in various parts of the world ocean, EOS, 89, p. 170, 2008. 
Kalberer, M., Fischer, G., Pätzold, J., Donner, B., Segl, M., and Wefer, G.: Seasonal sedimentation and stable isotope records of pteropods off Cape Blanc, Mar. Geol., 113, 305-320, 1993.

Karakas, G., Nowald, N., Blaas, M., Marchesiello, P., Frickenhaus, S., and Schlitzer, R.: High-resolution modeling of sediment erosion and particle transport across the northwest African shelf, J. Geophys. Res., 111. C06025, doi:10.1029/2005JC003296, 2006.

Karakas, G., Nowald, N., Schäfer-Neth, C., Iversen, M. H., Barkmann, W., Fischer, G., Marchesiello, P., and Schlitzer, R.: Impact of particle aggregation on vertical fluxes of organic matter, Prog. Oceanogr., 83, 331-341, 2009.

Kempler, S. J.: NASA/Goddard Flight Space Center, GIOVANNI, http://giovanni.sci.gsfc.nasa.gov/giovanni/?instance_id=ocean_ month, 2015.

Kaufman, Y. J., Koren, I., Remer, L. A., Tanré, D., Ginoux, P., and Fan, S.: Dust transport and deposition from the Terra-Moderate Resolution Imaging Spectroradiometer (MODIS) spacecraft over the Atlantic Ocean, J. Geophys. Res., 110, D10S12, doi:10.1029/2003JD004436, 2005.

Klaas, C. and Archer, D. E.: Association of sinking organic matter with various types of ballast in the deep sea: Implications for the rain ratio, Global Biogeochem. Cy., 16, 1116, doi:10.1029/2001GB001765, 2002.

Kremling, K., Lentz, U., Zeitzschell, B., Schulz-Bull, D. E., and Duinker, J. C.: New type of time-series sediment trap for the reliable collection of inorganic and organic trace chemical substances, Rev. Scient. Instr., 67, 4360-4363, 1996.

Kushnir, Y.: Interdecadal variations in North Atlantic sea surface temperature and associated atmospheric conditions, J. Climate, 7, 141-157, 1994.

Lathuilière, C., Echevin, V., and Levy, M.: Seasonal and intraseasonal surface chlorophyll-a variability along the northwest African coast, J. Geophys. Res.-Ocean., 13, C05007, doi:10.1029/2007JC004433, 2008.

Lucio, P. S., Baldicero Molion, L. C., de Avial-Valadão, C. E., Conde, F. C., Malheiro Ramos, A., and Dias de Melo, M. L.: Dynamical outlines of the rainfall variability and the ITCZ role over the West Sahel, Atmos. Clim. Sci., 2, 337-350, 2012.

Marcello, J., Hernandez-Guerra, A., Eugenio, F., and Fonte, A.,: Seasonal and temporal study of the northwest African upwelling system, Int. J. Remote Sens., 32, 1843-1859, 2011.

McGregor, H. V., Dima, M., Fischer, H. W., and Mulitza, S.: Rapid 20th century increase in coastal upwelling off Northwest Africa, Science, 315, 637-639, 2007.

Meunier, T., Barton, E. D., Barreiro, B., and Torres, R.: Upwelling filaments off Cape Blanc: interaction of the NW African upwelling current and the Cape Verde frontal zone eddy field?, J. Geophys. Res.-Ocean., 117, C08031, doi:10.1029/2012JC007905, 2012.

Mittelstaedt, E.: The ocean boundary along the northwest African coast: Circulation and oceanographic properties at the sea surface, Prog. Oceanogr., 26, 307-355, 1991.

Moulin, C. and Chiapello, I.: Evidence of the control of summer atmospheric tansport of African dust over the Atlantic by Sahel sources from TOMS satellites (1979-2000), Geophys. Res. Lett., 31, L02107, doi:10.1029/2003GL019031, 2004.

Müller, P. J. and Schneider, R.: An automated leaching method for the determination of opal in sediments and particulate matter, Deep-Sea Res. Pt. I, 40, 425-444, 1993.
Muller-Karger, F. E., Varela, R., Thunell, R., Luerssen, R., Hu, C., and Walsh, J. J.: The importance of continental margins in the global carbon cycle, Geophys. Res. Lett., 32, L01602, doi:10.1029/2004GL021346, 2005.

Narayan, N., Paul, A., Mulitza, S., and Schulz, M.: Trends in coastal upwelling intensity during the late 20th century, Ocean Sci., 6, 815-823, doi:10.5194/os-6-815-2010, 2010.

Neuer, S., Torres-Padron, M.E., Gelado-Caballeo, M.D., Rueda, M.J., Hernandez-Brito, J., Davenport, R., and Wefer, G.: Dust deposition to the eastern subtropical North Atlantic gyre: Does ocean's biogeochemistry respond?, Global Biogeochem. Cy., 18, GB4020, doi:10.1029/2004GB002228, 2004.

Nicholson, S. E.: The West African Sahel: A review of recent studies on the rainfall regime and its interannual variability, ISRN Meteorology, 2013, 453521, doi:10.1155/2013/453521, 2013.

Nowald, N., Iversen, M. H., Fischer, G., Ratmeyer, V., and Wefer, G.: Time series of in-situ particle properties and sediment trap fluxes in the coastal upwelling filament off Cape Blanc, Mauritania, Prog. Oceanogr. Pt. A, 137, 1-11, 2015.

N'Tchayi Mbourou, G., Berrand, J. J., and Nicholson, S. E.: The diurnal and seasonal cycles of wind-borne dust over Africa north of the equator, J. Appl. Meteorol., 36, 868-882, 1997.

Nykjaer, L. and Van Camp, L.: Seasonal and interannual variability of coastal upwelling along northwest Africa and Portugal from, 1981 to 1991, J. Geophys. Res., 99, 197-207, 1994.

Pauly, D. and Christensen, V.: Primary production required to sustain global fisheries, Nature, 374, 255-257, 1995.

Ploug, H., Iversen, M. H., and Fischer, G.: Ballast, sinking velocity, and apparent diffusivity within marine snow and zooplankton fecal pellets: implications for substrate turnover by attached bacteria, Limnol. Oceanogr., 53, 1878-1886, 2008.

Pradhan, Y., Lavender, S. J., Hardman-Mountford, N. J., and Aiken, J.: Seasonal and inter-annual variability of chlorophyll-a concentration in the Mauritanian upwelling: observation of an anomalous event during 1998-1999, Deep-Sea Res. Pt. II, 53, 15481559, 2006.

Prospero, J. M.: Mineral-aerosol transport to the North Atlantic and North Pacific: The impact of African and Asian sources, in: The long range atmospheric transport of natural and contaminant substances, edited by: Knap, A. H., Dordrecht, Mathematical and Physical Sciences, Kluwer Academic Publishers, 19-52, 1990.

Prospero, J. M. and Lamb, P. J.: African droughts and dust transport to the Caribbean: climate change implications, Science, 302, 1024-1027, 2003.

Ratmeyer, V., Fischer, G., and Wefer, G.: Lithogenic particle fluxes and grain size distributions in the deep ocean off northwest Africa: Implications for seasonal changes of aeolian dust input and downward transport, Deep-Sea Res. Pt. II, 46, 1289-1337, 1999a.

Ratmeyer, V., Balzer, W., Bergametti, G., Chiapello, I., Fischer, G., and Wyputta, U.: Seasonal impact of mineral dust on deepocean particle flux in the eastern subtropical Atlantic Ocean, Mar. Geol., 159, 241-252, 1999b.

Redfield, A. C., Ketchum, B. H., and Richards, F. A.: The influence of organisms on the composition of seawater, in: The Sea, edited by: Hill, M. N., Wiley and Sons, Chichester, 2, 26-77, 1963.

Romero, O. E., Lange, C. B., Swap, R. J., and Wefer, G.: Eoliantransported freshwater diatoms and phytoliths across the equato- 
rial Atlantic record temporal changes in Saharan dust transport patterns, J. Geophys. Res., 104, 3211-3222, 1999.

Romero, O. E., Lange, C. B., and Wefer, G.: Interannual variability (1988-1991) of siliceous phytoplankton fluxes off northwest Africa, J. Plank. Res., 24, 1035-1046, 2002.

Romero, O. E., Kim, J.-H., and Donner, B.: Submillennial-tomillennial variability of diatom production off Mauritania, NW Africa, during the last glacial cycle, Paleoceanography, 23, PA3218, doi:10.1029/2008PA001601, 2008.

Shanahan, T. M., Overpeck, J. T., and Anchukaitis, K. J., Beck, J. W., Cole, J. E., Dettman, D. L., Peck, J. A., Scholz, C. A., and King, J. W.: Atlantic Forcing of persistent drought in West Africa, Science, 324, 377-380, 2009.

Siegel, D. A. and Deuser, W. G.: Trajectories of sinking particles in the Sargasso Sea: modeling of statistical funnels above deepocean sediment traps, Deep-Sea Res. Pt. I, 44, 1519-1541, 1997.

Stokes, D. C.: NOAA, IRI/LDEO Climate Data Library, http://iridl. ldeo.columbia.edu/filters/.NINO/SOURCES/.NOAA/.NCEP/ .EMC/.CMB/.GLOBAL/.Reyn_SmithOIv2/.monthly/.ssta/, 2015.

Ternon, E., Guieu, C., Loÿe-Pilot, M.-D., Leblond, N., Bosc, E., Gasser, B., Miquel, J.-C., and Martín, J.: The impact of Saharan dust on the particulate export in the water column of the North Western Mediterranean Sea, Biogeosciences, 7, 809-826, doi:10.5194/bg-7-809-2010, 2010.

Thunell, R., Benitez-Nelson, C., Varela, R., Astor, Y., and MullerKarger, F.: Particulate organic carbon fluxes along upwellingdominated continental margins: rates and mechanisms, Global Biogeochem. Cy., 21, GB1022, doi:10.1029/2006GB002793, 2007.
US Department of Commerce: NOAA Earth System Research Laboratory, http://www.esrl.noaa.gov/psd/data/timeseries/AMO/, 2015.

Van Camp, L., Nykjær, L., Mittelstaedt, E., and Schlittenhardt, P.: Upwelling and boundary circulation off Northwest Africa as depicted by infrared and visible satellite observations, Prog. Oceanogr., 26, 357-402, 1991.

Yeager, S. G., Shields, C. A., Large, W. G., and Hack, J. J. : The Low-Resolution CCSM3, J. Climate, 19, 2545-2566, 2006.

Yu, E. F., Francois, R., Honjo, S., Fleer, A. P., Manganini, S. J., Rutgers van der Loeff, M. M., and Ittekkot, V.: Trapping efficiency of bottom-tethered sediment traps estimated from the intercepted fluxes of ${ }^{230} \mathrm{Th}$ and ${ }^{231} \mathrm{~Pa}$, Deep-Sea Res. Pt. I, 48, 865-889, 2001.

Zeeberg, J., Corten, A., Tjoe-Awie, P., Coca, J., and Hamady, B.: Climate modulates the effects of Sardinella aurita fisheries of Northwest Africa, Fish. Res., 89, 65-75, 2008.

Zenk, W., Klein, B., and Schroder, M.: Cape Verde Frontal Zone, Deep-Sea Res. Pt. I, 38, 505-530, 1991.

Zhao, T. X.-P., Laszlo, I., Guo, W., Heidinger, A., Cao, C., Jelenak, A., Tarpley, D., and Sullivan, J.: Study of long-term trend in aerosol optical thickness observed from operational AVHRR satellite instrument, J. Geophys. Res., 113, D07201, doi:10.1029/2007JD009061, 2008. 